\title{
The response of tropical rainforests to drought - lessons from recent research and future prospects
}

\author{
Damien Bonal $^{1} \cdot$ Benoit Burban $^{2} \cdot$ Clément Stahl $^{3,4} \cdot$ Fabien Wagner $^{5} \cdot$ Bruno Hérault $^{3}$
}

Received: 3 February 2015 /Accepted: 24 August 2015 / Published online: 25 September 2015

(C) INRA and Springer-Verlag France 2015

\begin{abstract}
- Key message We review the recent findings on the influence of drought on tree mortality, growth or ecosystem functioning in tropical rainforests. Drought plays a major role in shaping tropical rainforests and the response mechanisms are highly diverse and complex. The numerous gaps identified here require the international scientific community to combine efforts in order to conduct comprehensive studies in tropical rainforests on the three continents. These results are essential to simulate the future of these ecosystems under diverse climate scenarios and to predict the future of the global earth carbon balance.

- Context Tropical rainforest ecosystems are characterized by high annual rainfall. Nevertheless, rainfall regularly fluctuates during the year and seasonal soil droughts do occur. Over the past decades, a number of extreme droughts have hit tropical rainforests, not only in Amazonia but also in Asia and Africa. The influence of drought events on tree mortality and growth
\end{abstract}

Handling Editor: Jean-Michel Leban

Contribution of the co-authors DB initiated this review and all authors significantly contributed to the writing.

Damien Bonal

bonal@nancy.inra.fr

Benoit Burban

benoit.burban@ecofog.gf

Clément Stahl

clement.stahl@ecofog.gf

Fabien Wagner

wagner.h.fabien@gmail.com

Bruno Hérault

bruno.herault@ecofog.gf

1 INRA, UMR «Ecologie et Ecophysiologie Forestières», Université de Lorraine-INRA, F-54280 Champenoux, France or on ecosystem functioning (carbon and water fluxes) in tropical rainforest ecosystems has been studied intensively, but the response mechanisms are complex.

- Aims Herein, we review the recent findings related to the response of tropical forest ecosystems to seasonal and extreme droughts and the current knowledge about the future of these ecosystems.

- Results This review emphasizes the progress made over recent years and the importance of the studies conducted under extreme drought conditions or in through-fall exclusion experiments in understanding the response of these ecosystems. It also points to the great diversity and complexity of the response of tropical rainforest ecosystems to drought.

- Conclusion The numerous gaps identified here require the international scientific community to combine efforts in order to conduct comprehensive studies in tropical forest regions. These results are essential to simulate the future of these ecosystems under diverse climate scenarios and to predict the future of the global earth carbon balance.

Keywords Carbon · Climate · Drought - Global change · Growth $\cdot$ Mortality $\cdot$ Soil $\cdot$ Tropical $\cdot$ Water

2 INRA, UMR «Ecologie des Forêts de Guyane», AgroParisTech-CIRAD-INRA-CNRS-Université de Guyane-Université des Antilles, Campus Agronomique, 97387 Kourou, Guyane Française, France

3 CIRAD, UMR «Ecologie des Forêts de Guyane», AgroParisTechCIRAD-INRA-CNRS-Université de Guyane-Université des Antilles, Campus Agronomique, 97387 Kourou, Guyane Française, France

4 University of Antwerpen, Campus Agronomique, 97387 Kourou, Guyane Française, France

5 National Institute for Space Research (INPE), São José dos Campos, SP 12227-010, Brazil 


\section{Introduction}

Human-induced climate changes have begun to deeply impact boreal and temperate forest ecosystems (e.g. Ciais et al. 2005), but whether they are already affecting ecological functions in tropical rainforests is still an open question. Answering this question is one of the greatest challenges for scientists studying global change and for community or functional ecologists, since tropical ecosystems represent $34 \%$ of gross primary terrestrial productivity (Beer et al. 2010) and play a major role in carbon and water cycles at the global scale.

Tropical regions are characterized by high annual rainfall and high evapotranspiration. Nevertheless, a strong seasonality in precipitation and solar radiation levels (partly determined by cloud cover) occurs in most tropical regions around the world. These variations are partly driven by atmospheric movements related to the latitudinal changes in the intertropical conversion zone; they may lead to soil drought conditions. In environmental science, drought is defined as "a prolonged period of scanty rainfall". This definition describes a "climatic" point of view, related to the amount of precipitation reaching the ground. However, depending on soil type, soil drainage conditions, evapotranspiration levels and depth of soil water extraction by roots, a period of scanty rainfall may — or may not - severely reduce the amount of soil water available to plants, animals or microbes. In this context, the literature on the effect of drought on tropical rainforest ecosystems does not systematically and precisely define what is meant by "drought". Therefore, comparison of drought effects is not so obvious. Nevertheless, three types of drought are intensively studied in the current literature on tropical rainforests: seasonal droughts, extreme droughts and experimental droughts:

- Seasonal droughts correspond to seasonal variations in rainfall at a given site. This definition is based on longterm observations of precipitation regimes. One can expect that tropical rainforests are adapted to endure these seasonal droughts, as species have evolved under these conditions. Nevertheless, these seasonal variations influence ecosystem functioning and we thereafter review the existing knowledge on their response.

- Extreme droughts correspond to a period of abnormally low rainfall. A number of extreme drought events hit the tropical regions around the world over the past decades. Some may be explained by El Niño-Southern Oscillation (ENSO) events (1982/1983, 1986/1987, 1997/1998) (in Marengo et al. 2011): they have been associated with a rise in equatorial ocean surface temperatures and possibly also with modifications in the movement of the intertropical convergence zone ( $\mathrm{Li}$ et al. 2006). However, in Amazonia, other major droughts are clearly unrelated to ENSO events $(1980,2005,2010)$; they are linked to elevated surface temperatures in the Atlantic Ocean (Marengo et al. 2008, 2011). These extreme events may differ in intensity and duration and in the location and number of epicentres (see for instance the drought in 2005 vs. 2010 as illustrated in Fig. 1; Lewis et al. 2011). They nevertheless strongly influence the functioning of tropical rainforests and even endanger them. Thereafter, we use the existing knowledge on their impact to emphasize the limits to which these ecosystems may adapt.

- Experimental droughts correspond to through-fall exclusion experiments (Fig. 2). A given percentage of precipitation can be excluded from a given zone, and local consequences on soil, tree or ecosystem functioning are monitored. The major drawback of this approach is the surface of the considered zone: it is usually reduced (usually less than one or a few hectares). Several experiments have yet been conducted in wet tropical or subtropical regions. A list of these experiments with corresponding references is given in Table 1. As for extreme drought events, these experiments bring highly valuable information on the mechanisms involved in the response of these ecosystems to drought.

Considering these three types of drought and their specific effects on tropical forest ecosystems, we separate in this review the effects of recurrent seasonal drought on ecosystem functioning to the ones of extreme droughts and experimental ones (cf. list in Table 2). We thus focus on (i) what can be learnt from seasonal drying and (ii) what might be the consequences of more intense and/or more frequent droughts in the future. The latter question is a burning one as global earth models have made it possible to simulate an increase in the frequency and intensity of drought events in tropical regions (e.g. Cox et al. 2004, 2013; Poulter et al. 2010). The earliest simulations were highly criticized and Steinkamp and Hickler (2015), based on a global modelling analysis, concluded that there has not been any general drying trend or increase in extreme mortality events in tropical forests over the past decades. Yet, at least for the Amazonian region, global climate models converge to simulate a change in rainfall regime in this region and drier conditions over the twenty-first century (Malhi et al. 2009). Our ability to evaluate the impact of climatic change on the functioning of tropical rainforest ecosystems in the future will depend on observational, experimental and modelling approaches which include extreme drought conditions.

In this context, a considerable effort is being made worldwide to better understand the effect of drought on carbon and water cycles in tropical ecosystems at different spatial (forest stand to region) or temporal (seasonal to yearly) scales. Major research programmes have been and are being conducted in Central and South America, Asia and Africa. Within this framework, numerous new results have been published over the past 5 years. Hereafter, we provide a comprehensive 
Fig. 1 a, b Satellite-derived standardized anomalies for dry season rainfall for the two most extensive droughts of the twentyfirst century in Amazonia. c, d The difference in the 12-month (October to September) maximum climatological water deficit (MCWD) from the decadal mean (excluding 2005 and 2010), a measure of drought intensity that correlates with tree mortality. a, c The 2005 drought; b, d the 2010 drought. Reproduced from Lewis et al. (2011) with authorization from the corresponding author

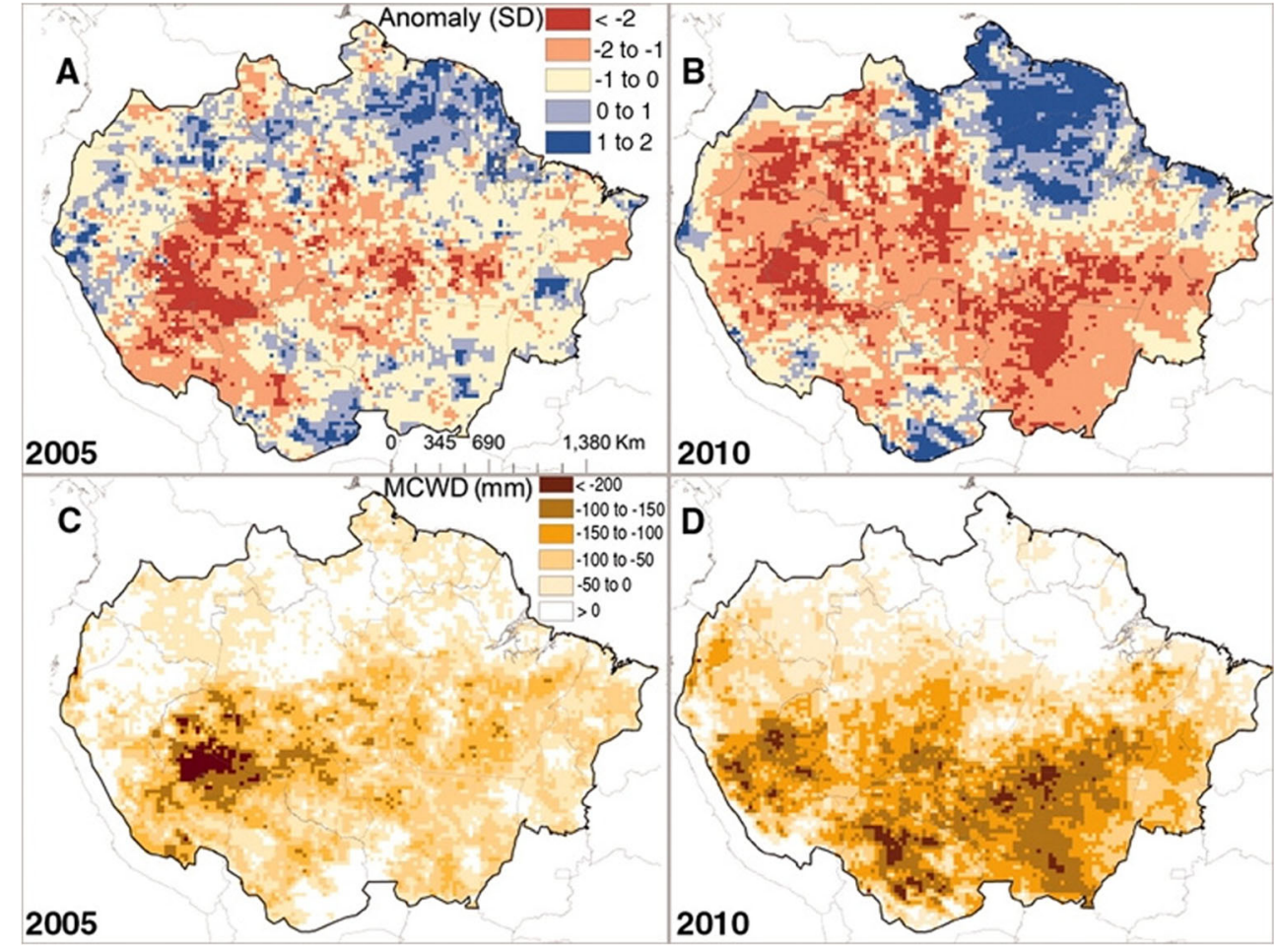

review of these recent studies and discuss whether we are currently able to evaluate the response of tropical rainforests to the future climate conditions in these regions. We also synthetize the existing knowledge on the mechanisms leading to these effects. Considerable knowledge has been accumulated on the physiological attributes of tropical rainforest tree species and their ability to support drought events. A review of this present knowledge would be highly valuable, but to keep the scope of this article within acceptable limits, we concentrate on community- and ecosystem-level responses to drought, rather than on tree- or species-level responses. We include 172 papers in this review, among which 88 were published over the past 5 years (2010-2015).

\section{The influence of drought on tropical rainforest ecosystems}

\subsection{Tree mortality}

As pointed out in Table 2, we were not able to find any information in the literature on the seasonal variations in mature tree mortality in tropical rainforest ecosystems. The main reason is that (i) tree mortality under non-exceptional years randomly occurs among seasons and (ii) seasonal droughtinduced mortality is hard to detect given that mortality is a punctual and rare phenomenon difficult to catch and model apart from exceptional events (Aubry-Kientz et al. 2013). This
Fig. 2 The rainfall exclusion experiment in Caxiuanã National Forest Reserve, Brazil (credits L. Rowland)

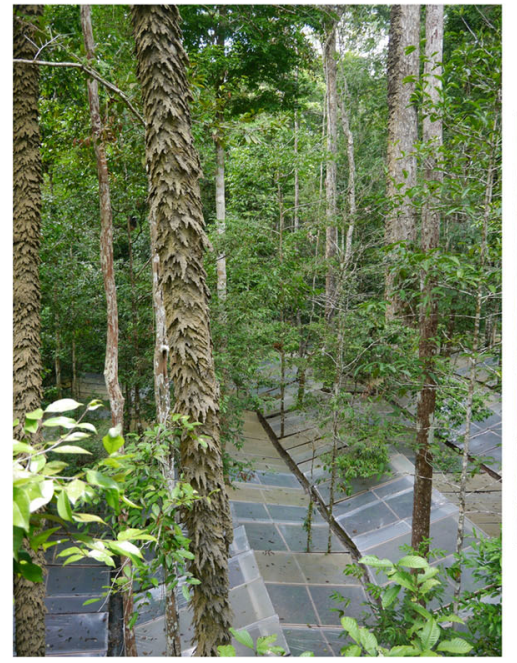

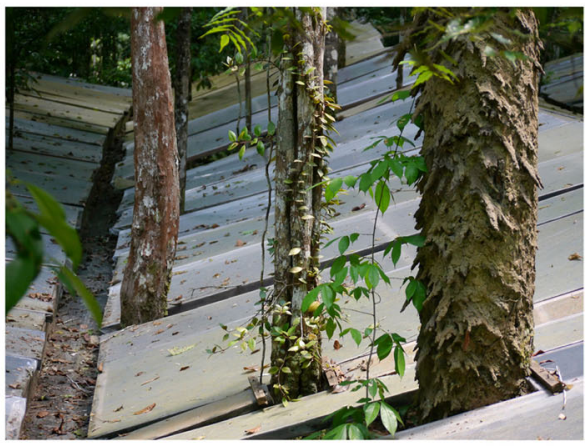


Table 1 List of through-fall exclusion experiments conducted in wet tropical or subtropical regions

\begin{tabular}{lllll}
\hline Site & Location & Climate & Period & Reference \\
\hline Daintree rainforest & Australia & Seasonal wet tropical & $2013-$ & http://www.jcu.edu.au/daintree \\
Caxiuanã National Forest Reserve & Brazil & Seasonal wet tropical & $2002-$ & Fisher et al. (2007) \\
Tapajós National Forest & Brazil & Seasonal wet tropical & $2000-$ & Nepstad et al. (2002) \\
Lore Lindu National Park & Indonesia & Aseasonal wet tropical & $2007-2009$ & Van Straaten et al. (2011) \\
FazendaVitória & Brazil & Seasonal wet tropical & $1993-1996$ & Cattânio et al. (2002) \\
Luquillo Experimental Forest & Puerto Rico & Aseasonal wet subtropical & 2009 & Wood and Silver (2012) \\
Golfo Dulce Forest Reserve & Costa Rica & Seasonal wet tropical & $2007-2008$ & Cleveland et al. (2010) \\
\hline
\end{tabular}

pattern is also consistent with the hypothesis that tropical rainforests are well-adapted to recurrent seasonal variations in soil water availability.

In contrast, the extreme drought that occurred in Amazonia in 2005 clearly resulted in abnormally high tree mortality rates (Phillips et al. 2009, 2010). Similar major die-off events were observed in Amazonia following an ENSO event (Williamson et al. 2000), in Panama (Condit et al. 1995), in tropical rainforests in China (2009-2010, 75 \% increase in mortality rate; Tan et al. 2013) and in East Kalimantan on Borneo Island following an ENSO event (10-20 \% increase in mortality rate; Slik 2004). Furthermore, in two sites in Amazonia (Caxiuanã and Tapajós) on long-term monitoring plots with through-fall exclusion, tree mortality also strongly increased (100\%) a few years after the beginning of the experiment compared to controls (da Costa et al. 2010). In contrast, no clear change in mortality rates was observed in Central Kalimantan,
Indonesia, after the 1997 drought (Nishimua et al. 2007). Increased mortality rates in extreme drought conditions as compared to recurrent seasonal droughts clearly point out to the limits that these ecosystems are able to support. These extreme drought events or experimental studies bring extremely valuable information to where these ecosystems can be pushed out by limited water conditions.

Comparing mortality rates after extreme drought events among sites distributed worldwide is perilous because climate conditions, species composition, soil conditions, history and drought severity differ. Nevertheless, Phillips et al. (2010) concluded that for comparable drought intensities, mortality rates in Asian tropical forests were stronger than in the Amazon. More intensive research programmes should be implemented so as to confirm such spatial trends and improve ecosystem and earth model simulations, particularly in poorly studied tropical rainforests like the ones in Africa and Asia: several

Table 2 List of tree- or ecosystem-level parameters included in this synthesis and summary results from the existing knowledge under experimental droughts, seasonal droughts or extreme drought events

\begin{tabular}{|c|c|c|c|}
\hline \multirow[t]{2}{*}{ Parameter } & \multicolumn{3}{|l|}{ Summary results from } \\
\hline & Experimental drought & Seasonal drought & Extreme drought \\
\hline Mortality & Increase (especially large trees) & & Increase (especially large trees) \\
\hline Tree growth & $\begin{array}{l}\text { Large trees and high-growth rate } \\
\text { trees negatively impacted }\end{array}$ & $\begin{array}{l}\text { Decrease likely due to change } \\
\text { in } \mathrm{C} \text { allocation }\end{array}$ & Reduced or even suppressed \\
\hline Net ecosystem exchange & & Contrasted patterns & Higher C uptake \\
\hline Gross primary productivity & & Moderate decrease & Moderate decrease \\
\hline Ecosystem respiration & & Moderate decrease & Strong decrease \\
\hline $\begin{array}{l}\text { Fluxes of greenhouse } \\
\text { gases other than } \mathrm{CO}_{2}\end{array}$ & & Decrease (but very few information) & \\
\hline Carbon balance & & Contrasted patterns & $\begin{array}{l}\text { Negate the positive fertilization } \\
\text { effect of atmospheric } \mathrm{CO}_{2}\end{array}$ \\
\hline Transpiration & $\begin{array}{l}\text { Decrease through regulation of } \\
\text { stomatal conductance }\end{array}$ & $\begin{array}{l}\text { Decrease through regulation } \\
\text { of stomatal conductance }\end{array}$ & \\
\hline Shifts in species composition & $\begin{array}{l}\text { Variability in mortality rates } \\
\text { within phylogeny }\end{array}$ & & $\begin{array}{l}\text { Shift to more xeric forest types } \\
\text { Increase in lianas? }\end{array}$ \\
\hline Phenology/litterfall/LAI & Slight decline in litterfall & Leaf renewal driven by solar radiation & Decrease in LAI \\
\hline Remote sensing approaches & & Green-up in dry season when water is not limited & Contrasted patterns \\
\hline Fire events & & & $\begin{array}{l}\text { Increase (especially in logged } \\
\text { and disturbed forests) }\end{array}$ \\
\hline
\end{tabular}


recent programmes funded by the European Commission (CARBOAFRICA, http://www.carboafrica.net) and by the National Science Foundation of China are currently making significant contributions to this much-needed research.

What mechanisms might explain the higher mortality events following extreme droughts? This question does not apply solely to tropical forest ecosystems, and a large and recent literature for various ecosystems around the world suggests that both carbon starvation and hydraulic failure processes are involved (e.g. Hartmann et al. 2015). The "carbon starvation hypothesis" was developed by McDowell et al. (2008) (see also the recent paper of McDowell et al. (2013) and Sevanto et al. 2014) and states that tree mortality occurs mainly because reduced photosynthesis during drought periods limits the accumulation of non-structural carbohydrate compounds in trees. In contrast, hydraulic failure occurs when xylem vessels are embolized. Several studies on tropical rainforests have clearly shown strong limitation of water transported through the xylem during dry periods (e.g. Sobrado 1997; Lopez et al. 2005; Fisher et al. 2006, 2007), thus supporting the hydraulic failure hypothesis. In contrast, Metcalfe et al. (2010b) suggest that the higher mortality in through-fall exclusion stands could be explained by carbon starvation. It is now well-known that these processes represent synergistic responses to drought, but the main issue now is to understand how these processes are linked. Because the methodologies used to assess the mechanisms causing tree mortality are complex and highly time-consuming and rely on the occurrence of major droughts, we still lack enough data to decipher and understand the origin of tropical tree mortality. This limits our ability to simulate the future of these ecosystems.

It is also important to note that several studies have reported that the increase in mortality in both through-fall exclusion studies (da Costa et al. 2010) and under natural conditions (Phillips et al. 2009, 2010) was higher for large trees than for small ones. This pattern was observed in Amazonia and Borneo (Phillips et al. 2010), but not in Asian forests (Aiba and Kitayama 2002; Itoh et al. 2012a, b). Higher mortality for large trees may be related to higher evaporative demand (higher vapour pressure deficit at the top of the canopy) (Saatchi et al. 2013) or to a higher risk of hydraulic failure because of tree height. Some other studies also reported slightly higher mortality rates for trees with low density wood than for those with higher density wood (Phillips et al. 2010; Aubry-Kientz et al. 2015). Part of these differences could be linked to differences in hydraulic failure among trees, as wood density is linked to xylem structure.

It is also important to remember that extreme mortality events can also have positive feedbacks on ecosystem dynamics and functioning. Standing dead trees and/or large fallen trees modify the structure of the canopy, increase canopy openness and enhance radiation within the canopy and on the ground..., thus changing local environmental conditions (Condit et al. 1996; Holmgren et al. 2001; Slik 2004). These conditions favour the establishment of fast growing trees and the growth of neighbouring trees, thus locally contributing to increased photosynthesis and ecosystem carbon uptake. Nevertheless, fast growing trees are characterized by low wood density and are likely to be more prone to embolism (e.g. Hacke et al. 2001). In the mid to long term, these changes may thus negatively influence the carbon balance of these forests. Whether the recent demonstration by Brienen et al. (2015) that the biomass dynamics of the Amazon rainforest over the past three decades show a long-term decreasing trend of carbon accumulation is consistent with this pattern is a worthy question.

\subsection{Tree growth}

Strong seasonal variations in tree growth (diameter increment) in tropical rainforests have been observed (Tian et al. 1998; Baker et al. 2003; Nepstad et al. 2004; da Costa et al. 2010; Stahl et al. 2010; Grogan and Schulze 2012; Wagner et al. 2012, 2013, 2014): a decrease in tree growth is usually observed during drought periods in inventory plots, followed by a strong increase at the onset of the rainy season.

Extreme droughts reduce tropical forest carbon storage by decreasing or even suppressing tree growth as compared to years with lower soil moisture deficits. Phillips et al. (2009) concluded that the 2005 extreme drought event in Amazonia halted the long-term increase in aboveground biomass (since the 1950s) in a significant number of study plots. It may be expected that water-stress-induced variation in tree growth response may be dependent to topographic position, as suggested by indirect observations (Silva et al. 2013), but there is a lack of evidence on that point.

The causes for a decline in tree growth under drought conditions are multiple:

(i) Firstly, a methodological remark must be made. Growth measurements based on dendrometer bands installed around tree trunks must be used with caution, since the bands react to bark thickness and may shrink during dry periods (because of a drier atmospheric air, e.g. Stahl et al. 2010). A decrease in trunk circumference during dry periods, or at least a decrease in circumference increment, could therefore be due to the shrinkage alone, or to a "real" decrease in tree growth (cell division in cambial tissues), or both. This widely used methodology has proven efficient to study long-term tree growth, but short-term variations (at seasonal scale) can lead to misinterpretation. Chitra-Tarak et al. (2015) have recently published a novel method to take this bias into account.

(ii) Soil water has been found to be a predominant driver of seasonal variations in tree growth. Reduced relative 
extractable water during drought periods was found to be the main environmental factors causing temporal variations in tree growth in an extensive study on 205 trees in French Guiana (Wagner et al. 2011). Precipitation and the duration of the drought season were the best predictors of tree growth variations in an African study (Ouédraogo et al. 2013). This was also the case in an overview across tropical regions (Wagner et al. 2014).

(iii) Third, solar radiation and daily minimum air temperature also contribute to seasonal variations in tree growth, though to a lesser extent than soil water availability (Clark et al. 2010; Wagner et al. 2012). The air temperature effect may be related to the limiting effect of high temperatures on photosynthesis. Interpreting the radiation effect is complex, as radiation may indeed influence photosynthesis levels. Yet, photosynthesis and growth are not directly linked: non-structural carbohydrates stored in trees also contribute to secondary growth, with various time lags (days to months) (Richardson et al. 2013).

The physiological mechanisms leading to seasonal variations in tree growth are not fully understood either. Secondary growth is known to decrease during drought periods when xylem embolism occurs, resulting in the disruption of water columns in the trunk and in branches and in the reduction of water supply to leaves (Tyree and Cochard 1996). The role of non-structural carbohydrate reserves should be considered too: these reserves may not only play a major role in explaining seedling survival during drought periods (Obrien et al. 2014). They may also influence intra-annual variations in tree growth (Würth et al. 2005; Richardson et al. 2013). Doughty et al. (2014) also emphasized the role of carbon allocation to the different tree compartments (leaf, fruit, branch and root) to explain seasonal variations in tree growth in Bolivian tropical rainforests. These authors even concluded that seasonal shifts in allocation (particularly the trade-off between above- and belowground compartments) rather than changes in productivity explain seasonal changes in tree growth.

Interestingly, drought does not influence growth in trees of different sizes or with differing growth rates in a similar way: long-term drought in through-fall exclusion experiments mainly affected the growth of large trees, whereas the small trees were barely impacted (da Costa et al. 2010). Similar trends were observed in natural forests in Amazonia and Africa (Ouédraogo et al. 2013; Phillips et al. 2009; Wagner et al. 2013, 2014). Furthermore, trees with high radial growth rates under moist conditions showed the strongest relative decrease under through-fall conditions in Indonesia (Moser et al. 2014). These effects are not intuitive since reduced soil water availability necessarily displays a vertical gradient: the top layers are usually drier than the deeper ones. One could therefore expect that trees with superficial roots would be affected the most. Yet, Stahl et al. (2013b) demonstrated that there is no clear relationship between tree size and soil water extraction depth during the dry season: small trees are also able to use water from deep soil layers. Other explanations may have to do with ontogenetic shifts in drought-adaptive capacities (Cavender-Bares and Bazzaz 2000) or in hydraulic failure/ carbon allocation strategies.

\subsection{Carbon fluxes}

An important consequence of higher mortality rates during broad-scale mortality events is the reduced capacity of impacted forests to absorb $\mathrm{CO}_{2}$ and the huge amounts of carbon that can be released into the atmosphere as the dead trees decomposed. This decomposition is slow (one to several decades) and varies widely according to wood density and branch or trunk size (Hérault et al. 2010). Direct, long-term measurements of carbon fluxes are recorded at various eddy flux tower sites in tropical rainforest ecosystems (now in Amazonia, Africa and Asia) and allow to characterize seasonal variations in carbon fluxes (Fig. 3). Gross primary productivity (GPP) and ecosystem respiration (ER) - the two $\mathrm{CO}_{2}$ fluxes that characterize the main exchange in carbon between the ecosystem and the atmosphere-usually decrease during seasonal droughts (see van der Molen et al. 2011 and Shi et al. 2014 for a review). This decrease is largely explained by physiological [down-regulation of leaf, trunk or root gas exchange; decrease in heterotrophic respiration] or structural [leaf senescence, leaf shed] changes.

One major result obtained thanks to these studies is that differential changes in ecosystem photosynthesis (GPP) and respiration (ER) during dry periods induce large seasonal variations in the ecosystem carbon balance, as determined by net ecosystem carbon exchange (NEE). NEE is calculated as the algebraic difference between ER and GPP [the ecosystem is considered to be a carbon sink when NEE is negative]. Large discrepancies in seasonal variations in NEE across tropical rainforests have been found. Some studies showed no clear effect of seasonal soil drought on NEE (Carswell et al. 2002). In contrast, other studies showed a decrease in carbon uptake during dry periods (Williams et al. 1998; Keller et al. 2004), whereas others showed higher [more negative] NEE values during dry seasons than during wet seasons (Saleska et al. 2003; Goulden et al. 2004; Baker et al. 2008; Bonal et al. 2008; Yan et al. 2013). At the latter sites, tropical rainforest ecosystems accumulate more carbon when water is a limiting factor than during the wet seasons. Some of these discrepancies could be related to the overestimation of ER in early studies that used the eddy covariance method (see Saleska et al. 2003; Kruijt et al. 2004). They also arise because of differences in species composition, soil conditions and partly also to drought stress levels reached at the sites. 


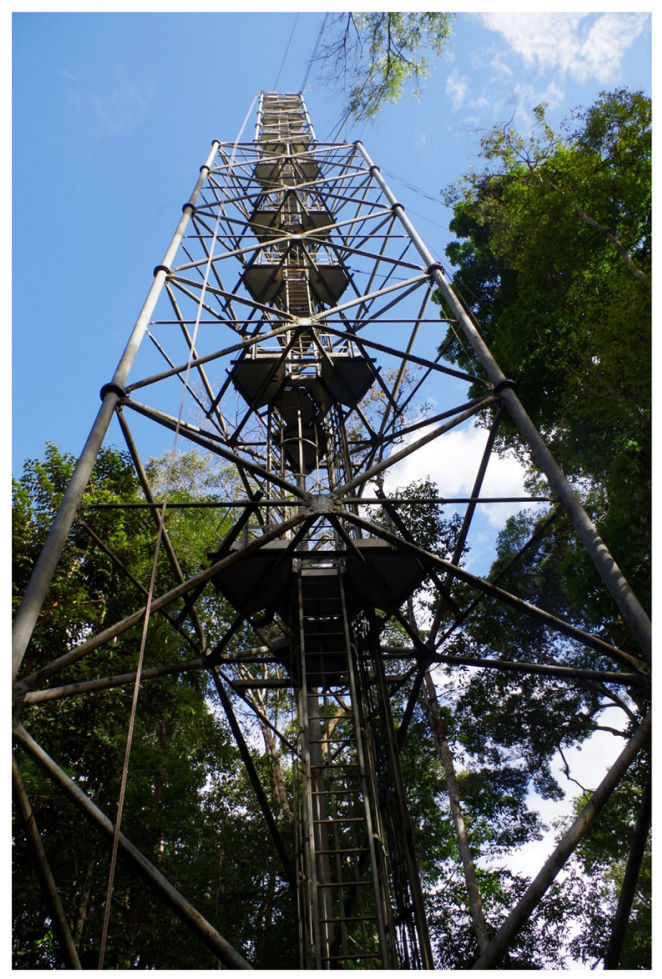

Fig. 3 The 55-m high eddy flux tower set up in 2003 in French Guiana (Bonal et al. 2008) (credits D. Bonal). Equipment installed on top of the tower (above the canopy) allows to continuously monitor the gas exchange $\left(\mathrm{CO}_{2}, \mathrm{H}_{2} \mathrm{O}\right)$ between the atmosphere and the considered ecosystem (around 50-100 ha)

Under extreme drought conditions, GPP is generally moderately further impacted by these extreme conditions, while the decrease in ER is usually much stronger than under recurrent seasonal droughts (synthetized in Shi et al. 2014). This suggests that drought severity could be driving the relative decrease in GPP and ER in these ecosystems. If this is verified, such patterns should be included in modelling approaches. A question which merits further attention then arises: what is the future of the carbon that is not released during severe dry periods, as compared to moderate dry ones? Is this carbon directly released to the atmosphere once heavy rainfalls occur or is it, partly or completely, stored in the ground?

The following mechanisms have been identified as contributing to the GPP and ER pattern under seasonal or extreme droughts:

(i) Tree root access to deep soil layers (Nepstad et al. 1994; Markewitz et al. 2010; Stahl et al. 2013b) limits the negative effect of reduced rainfall on photosynthetic activity. Indeed, though the root biomass of tropical rainforest trees is concentrated in the upper soil layers (Nepstad et al. 1994), deep roots still play a crucial role in the water and carbon cycles in these ecosystems (Nepstad et al. 1994; Stahl et al. 2013b). When soil water becomes limited in the upper soil layers, deep roots may provide water to the trees and thus help to prevent, or at least delay, the down-regulation of carbon and water fluxes. Reduced rainfall conditions over several weeks or even months do not always result in an instantaneous lack of water for deep-rooted trees; delayed drought effects may be observed. The GPP of deep-rooted trees may therefore remain high during drought events.

(ii) An increase in GPP could be expected during dry periods because of the production of new leaves (RestrepoCoupe et al. 2013) and increased radiation [reduced cloud cover] as compared to wet periods (Huete et al. 2006; Brando et al. 2010; Samanta et al. 2012). The negative effect of reduced solar radiation on tree photosynthesis and growth during the wet season was experimentally demonstrated by Graham et al. (2003). This argument was also used by Condit et al. (2004) to explain high tree growth rates during the 1997-1998 ENSO event. However, this potential increase may be counterbalanced to some extent by the negative effect of drought on photosynthesis for the shallow-rooted trees when the dry season is moderate, or for most trees if the decrease in soil water availability is severe. The opposite trend between these different effects explains the complexity of the seasonal variations in GPP.

(iii) ER is the sum of the $\mathrm{CO}_{2}$ efflux from all the ecosystem compartments. One can expect a physiologically driven decrease in cell respiration under drought (see Atkin and Macherel 2009 for a review), but contrasting results have been published for tropical rainforest trees. A decrease in the $\mathrm{CO}_{2}$ efflux from the leaves, trunks and coarse woody debris was found in several studies (Chambers et al. 2000, 2001; Nepstad et al. 2002; Stahl et al. 2011, 2013a; Rowland et al. 2013, 2014). However, others showed slightly higher autotrophic (root and leaf) $\mathrm{CO}_{2}$ fluxes under dry conditions (Metcalfe et al. 2010a, b; da Costa et al. 2014). Similarly, contrasting changes in soil $\mathrm{CO}_{2}$ efflux have been found: a decrease in total soil respiration was observed in numerous studies (Araujo et al. 2002; Goulden et al. 2004; Hutyra et al. 2007; Bonal et al. 2008). However, though some through-fall exclusion manipulation experiments confirmed this decrease (Sotta et al. 2007; Van Straaten et al. 2011; Wood and Silver 2012), other studies showed no effect of water exclusion on heterotrophic soil respiration (Davidson et al. 2008) and one even found an increase (total soil respiration; Cleveland et al. 2010). These discrepancies could be related to differences in soil type and potential local ecosystem and carbon cycling adaptations to climatic conditions (Cleveland et al. 2010). However, the levels of drought stress reached at the study sites (seasonal vs. extreme) and the duration of the drought do not seem to 
contribute to explain these differences. These results underline the complexity of the carbon cycle in tropical ecosystems submitted to drought and make it difficult to simulate these response patterns with ecosystem or earth models.

\subsection{Transpiration}

Tropical rainforests play a major role in the global climate system because they exchange huge amounts of water and energy with the atmosphere. Droughts of varying intensity modify the hydrological cycle over these ecosystems (Gloor et al. 2013). When tropical rainforests suffer from seasonal drought, a decrease in tree- and ecosystem-level evapotranspiration is observed (Bonal et al. 2000; Stahl et al. 2013a). When the drought conditions become harsher, the decrease in tree transpiration is much stronger, and Fisher et al. (2007) concluded that tree water use was restricted to $20 \%$ of that in the control plots in a through-fall exclusion experiment. However, it is important to keep in mind that a decrease in evapotranspiration during a drought period actually reflects the combination of two opposite effects. First, high solar radiation during dry periods induces high evaporative demand [drier and warmer atmospheric air] that should theoretically lead to higher evapotranspiration rates. As an example, Fisher et al. (2007) confirmed higher transpiration during the dry season than during the wet season in Brazil. Second, a decrease in soil water availability leads to the down-regulation of stomatal conductance and thus to lower tree transpiration (Bonal et al. 2000; Stahl et al. 2013a). This generally observed decrease in transpiration during droughts suggests a predominant down-regulation of transpiration (reduction in soil-toroot conductance and water transport) when soil water availability is strongly limited. Nevertheless, the effect of soil water drying and strong evaporative demand on stomatal regulation can be diverging (Tardieu and Simonneau 1998; Tardieu et al. 2010). The complexity of these effects should not be overlooked when investigating observed patterns, particularly in modelling analyses.

\section{What faces tropical rainforests in the future?}

\subsection{Species composition}

Based on biogeographical, taxonomic or molecular biology studies, it has now been widely accepted that the tree species composition in tropical rainforests evolved during the Late Pleistocene and Holocene periods in conjunction with the occurrence of drier and cooler periods (Mayle et al. 2000). Even though major parts of tropical rainforests may have been remarkably resilient to dry climatic conditions (Mayle and
Power 2008), the current species composition of these forests is directly linked to past climate changes (Liu and Colinvaux 1985).

Just as the tropical rainforest communities of today were shaped by past climate changes, so will tropical species distribution, community composition and diversity be altered if climate conditions drastically change in the near future (Slik 2004; Engelbrecht et al. 2007; da Costa et al. 2010). Malhi et al. (2009) simulated that future climate conditions over Amazonia will be favourable for seasonal forests rather than for dry tropical forest or dry savannahs. In contrast, some global vegetation models predict a dramatic shift of the biome in Amazonia towards dry forests or even woodland savannahs (Cox et al. 2004; Chave 2014). These predictions are somehow catastrophic considering the known resilience of these ecosystems to drought events during the Holocene (Mayle and Power 2008). Nevertheless, they are supported by a few observations in tropical rainforests where local species composition and community functioning appear to shift over two to three decades towards more xeric types, if soil water conditions are frequently limited (e.g. Condit 1998; Enquist and Enquist 2010). This shift is associated with the contrasting vulnerability of tropical species to drought: for certain taxa, or size classes, or growth characteristics (fast vs. slow growing), or successional status (early vs. late stage), some species are subject to disproportionate mortality. Through-fall exclusion experiments have also revealed a strong variability among tree species, or tree genii, in their mortality rates (da Costa et al. 2010; Nepstad et al. 2007). A precise description of the functional characteristics of tropical tree species and their physiological and morphological response to drought is far from being complete. Nevertheless, important screenings of traits related to drought have been conducted over the past decades (e.g. Bonal et al. 2000; Engelbrecht et al. 2002, 2007; Engelbrecht and Kursar 2003; Bartlett et al. 2012; Fortunel et al. 2014). The vulnerability of tropical tree species to prolonged droughts diverges and is related to intrinsic differences in various leaf (e.g. turgor loss point, osmotic potential, stomatal closure, leaf thickness, specific leaf area, water use efficiency) and wood biological properties (e.g. xylem vessel size, wood specific gravity). Further comprehensive studies on the functional characteristics of tree species in Amazonia, Africa and Asia are still required.

As an example of shift in species composition, an increase in lianas, both in terms of individuals and biomass, has been documented over the past decade in tropical rainforests (see Schnitzer and Bongers 2011 for an overview). This change in distribution may have various origins (increasing forest disturbance, changes in land use, forest fragmentation...), but it has also been suggested that climate changes, along with extreme drought events, could be playing a major role. This remains to be proven; observations are recent and correlative changes are under study. Nevertheless, lianas are known to 
benefit, to the detriment of tree species, from drier air (increased evaporative demand) or soils (decreased soil water availability) (Schnitzer 2005; Schnitzer and Bongers 2011). Climatic conditions in the future may continue to be favourable to lianas and allow them to colonize new tropical rainforests, or at least to accentuate their contribution to ecosystem biomass and productivity.

These functional considerations should not hide one very important aspect in community ecology: tropical rainforests are the most diverse forests in the world (at least in terms of tree species). For a large range of ecosystem services, more diverse forest ecosystems perform better that pure ones because of positive interactions among tree species for resource acquisition (facilitation or niche differentiation mechanisms; see Cardinale et al. 2012 for a review). Basic theoretical ecology also suggests that biodiversity insures ecosystems against alteration of ecosystem functions, the insurance hypothesis (Yachi and Loreau 1999). Numerous species with a broad range of functional characteristics provide greater ecological overlaps so that if some species are loss, the remaining ones maintain similar levels of ecosystem functioning. In contrast, Mouillot et al. (2013) recently demonstrated the major role of rare species and functional vulnerability in the stability of ecosystem functioning. Unfortunately, very few studies on the relationship between biodiversity and ecosystem functioning have been conducted in tropical regions and those few mainly concern experimental plantations (e.g. Potvin and Gotelli 2008; Forrester 2014). Tropical rainforests with different levels of species diversity or with different species composition may respond differently to future droughts. A completely new area in ecological research is needed to answer this question.

\subsection{Phenology patterns}

Tropical rainforests are composed of species that cover the full range of leaf phenology patterns (i.e. emergence and fall), from strict deciduousness to evergreen (Loubry 1994; Viennois et al. 2013). The leaf area index (LAI) in these ecosystems remains high all year long and they are therefore classified as evergreen forests. Nevertheless, inconsistent seasonal patterns in LAI have been observed in Amazonia. Malhado et al. (2009) and Wagner et al. (2013) observe no seasonal change in LAI, whereas several studies conclude to clear seasonal dynamics in LAI or litterfall (e.g. Juarez et al. 2009). A peak in litterfall is usually observed during the early stages of the dry season in Amazonia (see Chave et al. 2010 for an overview). The origin of this later pattern remains unexplained: reduced water availability does not seem to provide an explanation (Wright and Cornejo 1990; Xiao et al. 2006; Miranda et al. 2011). Seasonal variations in leaf phenology were found to be driven by solar irradiance (Wright and van Schaik 1994; Xiao et al. 2006; Wagner et al. 2013). The peak in leaf fall coincides with a peak in radiation (Wagner et al. 2013) and is associated with a greater emergence of new leaves at the onset and during the dry season, a period when cloud cover is usually low or absent and solar radiation is therefore strong. Kim et al. (2012) showed that including a light-controlled phenology module into a terrestrial biosphere model (ED2 model) strongly improved its ability to capture seasonal patterns in net ecosystem productivity and litterfall fluxes. The greater proportion of young leaves during the dry season could enhance carbon assimilation during the dry season and at the onset of the wet season, at least as long as stomatal regulation related to drought stress does not limit photosynthesis. Indeed, young leaves are characterized by higher photosynthetic capacity than mature or senescent ones. However, this argument has been contradicted by studies showing a delayed development of the photosynthetic apparatus in young tropical rainforest leaves and lower photosynthetic efficiency compared to mature ones (Kursar and Coley 1992).

When considering the influence of extreme drought events, strong changes in ecosystem leaf area were indeed observed (Hilker et al. 2014). However, interestingly, long-term through-fall experiments showed no clear impact of severe drought on litterfall over the first and second year (Brando et al. 2008); a slight decline in litterfall compared to control plots occurred only at the third year. This pattern confirms the drought resistance of tropical ecosystems when an extreme event does not last too long, but also the limits to this resistance.

Optical remote sensing has been widely used over the past decade to analyse the effect of extreme drought on ecosystem phenology at various time scales and over large areas. After the discovery - using satellite measurements - of an unexpected canopy green-up during the dry season in Amazonia during the 2000-2005 period (Huete et al. 2006), Saleska et al. (2007) detected an increase of this green-up during the extreme dry season in 2005. This green-up was interpreted as being consistent with the leaf flush usually observed during dry conditions. However, Samanta et al. (2010) - and more recently Morton et al. (2014) - argued that these conclusions were based on irreproducible data and potential artefacts: the satellite data quality [partly due to cloud cover] may not have been good enough to support such a strong interpretation. The authors then concluded that no increase in green-up actually occurred during extreme drought events, a result consistent with the decline in greenness (less photosynthesis) during the 2010 drought event over Amazonia (Xu et al. 2011). However, an increase in greenness was recently observed by Maeda et al. (2014) during the dry season, even after correcting for all potential sun/sensor geometry artefacts. These results are clearly contradictory and a recent study tempted to reconcile these diverging views (Hilker et al. 2014). These authors conclude that the new, better quality satellite data such as those obtained with C5-MODIS 
eliminate such potential artefacts and that the occurrence of canopy cover green-up during seasonal dry periods, or extreme ones, depends on whether trees can access to deep soil water. As a result, some parts of the Amazon forest do show green-up during the dry season, though limited, since, during the cloudy wet season, the reduced light limits ecosystem photosynthesis. However, in other parts of the Amazon forest where tree access to soil water is severely limited, no greening-up occurs; a decline in greenness may even be observed via satellite. Studying tropical forest phenology with satellites data is thus feasible, but precisely assessing the impact of severe drought events is not yet fully solved (Hilker et al. 2014).

\subsection{Carbon balance}

Considerable literature over the past decade has demonstrated the positive role of tropical rainforests in capturing large amounts of atmospheric $\mathrm{CO}_{2}$ (e.g. Baker et al. 2004; Malhi et al. 2004; Ichii et al. 2005; Lewis et al. 2009; Phillips et al. 2009; Pan et al. 2011). Net aboveground biomass gain has been confirmed on numerous inventory plots in Amazonia or Africa: Phillips and Lewis (2014) estimate that the relative rate of increase is around 0.30 and $0.29 \%$ for Amazonia and Africa, respectively. Accumulation of carbon in the tropical terrestrial biosphere strongly contributes to slowing the rate of increase of $\mathrm{CO}_{2}$ into the atmosphere, thus reducing the greenhouse gas effect. Undisturbed tropical rainforests have been acting as a strong carbon sink in this way for decades.

The question now is whether they will be able to continue playing this role under future climate, particularly if the occurrence of extreme drought events increases. The large mortality event associated with the extreme 2005 drought in Amazonia was equivalent to several decades-worth of carbon accumulated by the tropical rainforest (Phillips et al. 2009; Gloor et al. 2012). A recent analysis of atmospheric $\mathrm{CO}_{2}$ measurements concluded that the unburned part of the Amazon basin [carbon release through fires is deducted in carbon balance calculations] shifted from a net carbon sink during a wet year to a carbon-neutral status during an extreme drought year (i.e. 2010) (Gatti et al. 2014). This shift was explained not only by changes in air temperature and vapour pressure deficit, but also by reduced soil water availability. An increase in the frequency of such major drought events in the future is therefore likely to modify the positive carbon uptake role played by undisturbed tropical rainforests and may negate the positive fertilization effect of increased $\mathrm{CO}_{2}$ concentrations (Cox et al. 2013). Yet, serious inconsistencies among simulation studies can be found: Phillips and Lewis (2014) reviewed the predictions concerning the carbon balance in Amazonian and African tropical rainforest ecosystems: in the future, these ecosystems may act as potential sinks, or become carbon sources, or have a neutral balance.
Furthermore, a recent pan-tropical study based on 150 years of tree ring analysis showed that increased atmospheric $\mathrm{CO}_{2}$ concentration induced an increase in intrinsic water use efficiency (the ratio of leaf $\mathrm{CO}_{2}$ assimilation over stomatal conductance) but not an increase in individual tree growth (van der Sleen et al. 2015).

The uncertainties around these simulations are largely related both to the structure and the parameterization of the global circulation vegetation models in use today. As for phenology patterns, a major challenge for remote sensing or modelling approaches is to reconcile satellite observations with observed measurements of ecosystem carbon fluxes and storage. A wide range of ecosystem or earth models have been elaborated and tested to date (e.g. Saleska et al. 2003; Ichii et al. 2007; Baker et al. 2008; Sitch et al. 2008; Fisher et al. 2010; Sakaguchi et al. 2011; Rowland et al. 2014) and a large body of literature addresses these issues. Though we will not discuss this literature in detail here, it is evident that no model is yet able to encompass all the complex plant- and ecosystem-water interactions under limiting soil water conditions. Solid improvements have been made over the past decade in matching the more mechanistic models with local observed data. Powell et al. (2013) perfectly summarizes the current state-of-the-art: “... terrestrial biosphere models are competent at predicting plant and ecosystem carbon fluxes under the present climate, but still require substantial development for predicting the consequences of severe drought scenarios.".

The influence of drought on the exchange of greenhouse gases other than $\mathrm{CO}_{2}$ between tropical rainforests and the atmosphere is rather unknown. A few studies conducted over the past decade showed significant seasonal variations in $\mathrm{N}_{2} \mathrm{O}$ or $\mathrm{CH}_{4}$ fluxes (Davidson et al. 2008; Itoh et al. 2012a, b; Wood and Silver 2012; Yan et al. 2014), but further comprehensive studies are required in order to include the effect of drought on these fluxes in ecosystem or earth models.

\subsection{Fires}

A major risk of future droughts - and one that may radically change species composition - is forest fire. Natural forest fires occasionally occurred in tropical rainforests throughout the Holocene period (Saldarriaga and West 1986) and contributed to shape the biogeography of the actual tropical rainforests.

Nevertheless, the major drought events of the past decades have resulted in an increased number of major forest fires in tropical rainforests (Cochrane et al. 1999; Alencar et al. 2006; Aragão et al. 2008). The risk of major fires is also expected to increase in the twenty-first century (Davidson et al. 2012). These fires have altered species composition and forest dynamics in large areas and will have long-term consequences on these ecosystems (Brando et al. 2014). Some evidence 
suggests that in tropical rainforests, selective logging (Siegert et al. 2001), pasture burning (Nepstad et al. 1999) and forest fragmentation (Cochrane and Barber 2009) lead to an increased susceptibility of the forest canopy to fire. This increase is due to a greater amount of dead wood in these forests, a lower relative humidity in the understory which increases the drying speed of the dead wood and a greater penetration of forests by human activities. For example, opening of the canopy by logging generates faster air movements in the canopy so that the increase in fire-line intensity in logged forests in the Amazon region is estimated to be twice as in intact forests (Cochrane 2003). Furthermore, drought-related forest fires obviously release huge amounts of carbon into the atmosphere (Grace et al. 2014): at the regional scale, Gatti et al. (2014) showed that forest fires occurring during the extreme 2010 drought contributed to shift the annual carbon balance of the Amazon basin from a carbon-neutral status to a strong carbon release zone $(0.48 \pm 0.18 \mathrm{Pg}$ of carbon per year). In addition to the direct effect of fires on carbon balance, carbon losses from tree mortality in fire-affected forests have been shown to be cumulative through time, with an increase in large tree mortality three years after the fire event (Barlow et al. 2003).

\section{Conclusions and research gaps}

As synthetized here, a huge effort has been made over the past decade to improve our understanding of the response of tropical rainforest ecosystems to seasonal variations in precipitation and to extreme soil water conditions. The existing literature points to the adaptive capacity of these ecosystems to support seasonal droughts, but also to the great diversity and complexity of this response. The recent extreme drought events that occurred in these regions, the studies conducted in experimental droughts and the ongoing modelling studies allowed to greatly improve our knowledge when these ecosystems are pushed out of the soil water conditions during recurrent seasonal droughts. We now have better ideas about the potential limits for the carbon and water cycle and balance of these ecosystems to support extreme drought conditions. Our ability to model this response and simulate the potential consequences of future climate conditions has thus greatly improved, but large uncertainties, and even some discrepancies, still exist. This effort should thus be continuously supported, considering the major role played by these ecosystems at the global scale.

We have identified a number of research gaps to fill in the current knowledge on the response of these ecosystems to severe drought conditions. We highlight the most important below. These gaps require the international scientific community to combine efforts in order to conduct comprehensive studies in tropical rainforests on the three continents. These results are essential not only to simulate the future of these ecosystems but also to predict the future of the global earth carbon balance.

\subsection{Taking combined stresses into account}

An important point to consider is that the increase in the intensity and frequency of drought events will be accompanied by other changes in environmental conditions, such as increases in temperatures, vapour pressure deficit or atmospheric $\mathrm{CO}_{2}$ concentrations. This review specifically targeted the effects of soil drought, but one must not lose sight of the consequences of other changes and of the potential feedback controls (Malhi et al. 2009; Cernusak et al. 2013). Niinemets (2010) concluded that tree response to combined stresses, though none of them may be extreme separately, can be much greater than tree response to one single extreme stress. A concerted research effort should therefore be made in the near future to study combined effects. Modelling studies or large-scale manipulation studies combining soil drought, increase in $\mathrm{CO}_{2}$ concentrations and temperature, or combining soil drought and nutrient levels should be encouraged in these forests to test the effect of these combined changes (Cavaleri et al. 2015).

\subsection{Relating species-level and ecosystem-level responses to extreme droughts}

Though we must maintain our research efforts, our understanding of tropical rainforest species vulnerability to drought has improved over the past decade. Ecosystem functioning depends on species composition and ecosystem response to drought results from each individual species response to drought. However, these responses do also depend on interactions among species (competition, facilitation), on interactions between species and their attendant microbial communities and on changes in species composition. Information about these interactions and changes is totally lacking. Manipulating species composition on large scales in these forests seems unrealistic, but building new models combining mechanistic and community dynamics approaches should help us understand the effects of climate changes on ecosystem functioning.

\subsection{Understanding the role of microbial communities}

There is evidence that plant resistance to drought is improved when fungal communities densely colonize the roots (e.g. Augé 2000; overview in Lehto and Zwiazek 2011). Yet, it has been shown that fungal community structure is strongly linked to tree species composition and tree species richness in tropical rainforests (Peay et al. 2013). A change in tree species composition would thus influence fungal communities and their role in ecosystem functioning. Studies on the role of fungal communities in ecosystem functioning in tropical rainforests are very rare. A comprehensive study of these 
interactions is needed in order to understand the impact of seasonal drought and extreme drought events on belowground microbial communities and clarify their role in ecosystem functioning under climate changes.

\subsection{Taking repetitive drought events into account}

Most observations on the effect of drought on ecosystem functioning, with but a few exceptions, are based on a single drought event. The impact of repetitive events is still far from being understood, as is the resilience of tropical ecosystems to these events. Phillips et al. (2010) pointed out that the extreme 2005 drought in Amazonia was still affecting mortality rates in these ecosystems 2 years after the drought. How well these ecosystems can adapt to more frequent severe drought events [ENSO-related or others] in the future remains unknown. Is the resistance of tropical rainforest trees weakened by a first extreme drought event which subsequently increases their vulnerability? The recent occurrence of extreme drought events at low intervals in Amazonia or Asia brings interesting opportunities to study the effect of recurrent drought events in situ.

\subsection{Assessing the adaptive potential of tropical rainforest tree species to droughts}

Change in species composition is one way these ecosystems can naturally adapt to severe drought conditions, but functional adaptive mechanisms can also take place. One can wonder how far such adaptive mechanisms can go and when their limits will be reached. Tree tolerance to environmental stresses increases throughout ontogeny: over the next century, trees that are young today may well prove able to adapt to upcoming climatic conditions. However, how well tropical tree species will adapt to drought over the long-term is largely unknown. Among the strategies species use to survive drought conditions, carbon allocation deserves serious studies. A major gap exists in our knowledge concerning how carbon allocation patterns change in tropical rainforest trees under varying environmental conditions, though a few recent studies have provided interesting results: a clear asynchronism between leaf production and tree growth was observed (Wagner et al. 2013). This pattern has recently been linked with a different timing in carbon allocation between compartments (Malhi et al. 2014; Rowland et al. 2014). The authors also demonstrated different allocation patterns between the above- and belowground compartments. As an example, Rowland et al. (2014) showed a shift in the allocation of photosynthetic products from foliage and wood in the wet season to fine roots in the dry season. These allocation patterns are likely complex since they undoubtedly vary with drought intensity (Brando et al. 2008; Doughty et al. 2014). Comprehensive screenings on species variability in carbon and nitrogen allocation patterns should be conducted: they should include the consequences of both recurrent seasonal variations as well as extreme drought events.

\subsection{Improving the ability of ecosystem or earth models to simulate drought responses}

Even though a strong effort has been made in the last decade to include as many fine-scale functional processes as possible in mechanistic forest ecosystem models or earth models (e.g. Fisher et al. 2007; Sakaguchi et al. 2011; De Weirdt et al. 2012; Powell et al. 2013; Rowland et al. 2014), their ability to simulate the future response of tropical ecosystems to major drought events remains inadequate. In the context of climate change, large uncertainties on future carbon stocks or fluxes persist (Poulter et al. 2010). These authors have identified research guidelines to improve the models, but to parameterize them, more observational and experimental data on the response of tropical ecosystems to drought events must be made available in concert. To improve simulations of climate change in the twenty-first century and its long-term effect on the ecosystem carbon balance, we should concentrate on phenology and mortality patterns and on $\mathrm{CO}_{2}$ and other greenhouse gas fluxes among the different compartments in the ecosystem, particularly autotrophic respiration.

\subsection{Evaluating the long-term impact of punctual extreme events}

Most studies published so far have addressed the short-term consequences of extreme droughts; only very few (mainly experimental through-fall studies) have attempted to evaluate their long-term impact (Fig. 4). Despite their tremendous value in the study of response mechanisms, experimental studies cannot mimic the impact of successive, high-frequency major

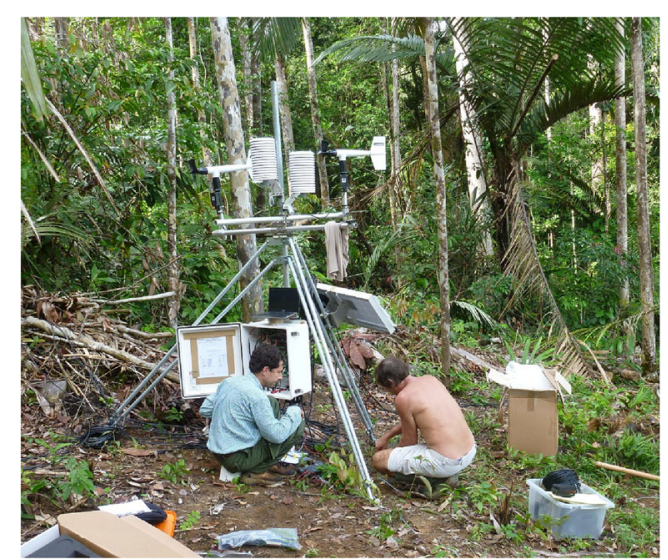

Fig. 4 Installation of an automatic weather station in the tropical rainforest in French Guiana (credits B. Hérault). Long-term monitoring of environmental conditions in remote forest inventory plots is a prerequisite to understand the effect of seasonal or extreme drought on tree and ecosystem functioning and simulate future changes 
droughts. The recent occurrence of several droughts in Amazonia and Asia with a return time lesser than 10 years may not give the forests time to completely recover between events and thus offers a major opportunity to evaluate the long-term impact of punctual extreme events. Remote sensing approaches provide the excellent tools to analyse these effects.

Acknowledgments This review was stimulated by discussions conducted during a meeting in Toulouse in 2014 funded by an Investissement d'Avenir grant from the ANR (CEBA: ANR-10-LABX-0025). We thank all the participants in this meeting who contributed to these discussions. We thank S. Lewis (University of Leeds, UK) for the rights to include Fig. 1 in this review and L. Rowland (University of Edinburgh, UK) for sharing recent pictures of the rainfall exclusion experiment in Caxiuanã, Brazil (Fig. 2).

Funding CS was supported by a grant from the "European Research Council Synergy", grant ERC-2013-SyG-610028 IMBALANCE-P. FW was supported by a grant from the "Fundação de Amparo à Pesquisa do Estado de São Paulo", Brazil, grant 13/14520-6.

\section{References}

Aiba SI, Kitayama K (2002) Effects of the 1997-98 El Nino drought on rain forests of Mount Kinabalu, Borneo. J Trop Ecol 18:215-230

Alencar A, Nepstad DC, Diaz MCV (2006) Forest understory fire in the Brazilian Amazon in ENSO and non-ENSO years: area burned and committed carbon emissions. Earth Interact 10:1-17

Aragão L, Malhi Y, Barbier N, Lima A, Shimabukuro Y, Anderson L, Saatchi S (2008) Interactions between rainfall, deforestation and fires during recent years in the Brazilian Amazonia. Philo Trans R Soc B-Biol Sci 363:1779-1785

Araújo AC, Nobre AD, Kruijt B, Elbers JA, Dallarosa R, Stefani P, Randow Von C, Manzi AO, Culf AD, Gash JHC, Valentini R, Kabat P (2002) Comparative measurements of carbon dioxide fluxes from two nearby towers in a central Amazonian rainforest: the Manaus LBA site. J Geophys Res 107 D20, 8090. doi:10.1029/2001JD000676

Atkin OK, Macherel D (2009) The crucial role of plant mitochondria in orchestrating drought tolerance. Ann Bot 103:581-597

Aubry-Kientz M, Hérault B, Ayotte-Trépanier C, Baraloto C, Rossi V (2013) Toward trait-based mortality models for tropical forests. PLoS ONE 8:e63678. doi:10.1371/journal.pone.0063678

Aubry-Kientz M, Rossi V, Wagner F, Hérault B (2015) Identifying climatic drivers of tropical forest dynamics. Biogeosci Discus 12:3145-3176

Augé RM (2000) Stomatal behavior of arbuscular mycorrhizal plants. In: Kapulnik Y, Douds DD (eds) Arbuscular mycorrhizas: physiology and function. Kluwer Academic, Dordrecht, pp 201-237

Baker IT, Prihodko L, Denning AS, Goulden M, Miller S, da Rocha HR (2008) Seasonal drought stress in the Amazon: reconciling models and observations. J Geophys Res 113:G00B01. doi:10.1029/ 2007JG000644

Baker TR, Burslem D, Swaine M (2003) Associations between tree growth, soil fertility and water availability at and regional scales in Ghanian tropical rain forest. J Trop Ecol 19:109-125

Baker TR, Phillips OL, Malhi Y, Almeida S, Arroyo L, Di Fiore A, Higuchi N, Killeen TJ, Laurance SG, Laurance WF, Lewis SL, Monteagudo A, Neill DA, Pitman NCA, Silva N, Vasquez RM (2004) Increasing biomass in Amazon forests. Philo Trans R Soc London 359:353-365

Barlow J, Peres CA, Lagan BO, Haugaasen T (2003) Large tree mortality and the decline of forest biomass following Amazonian wildfires. Ecol Lett 6:6-8
Bartlett M, Scoffoni C, Sack L (2012) The determinants of leaf turgor loss point and prediction of drought tolerance of species and biomes: a global meta-analysis. Ecol Lett 15:393-405

Beer C, Reichstein M, Tomelleri E, Ciais P, Jung M, Carvalhais N, Rödenbeck C, Arain MA, Baldocchi D, Bonan GB, Bondeau A, Cescatti A, Lasslop G, Lindroth A, Lomas M, Luyssaert S, Margolis H, Oleson KW, Roupsard O, Veenendaal E, Viovy N, Williams C, Woodward FI, Papale D (2010) Terrestrial gross carbon dioxide uptake: global distribution and covariation with climate. Science 329:834-838

Bonal D, Barigah TS, Granier A, Guehl JM (2000) Late stage canopy tree species with extremely low $\delta^{13} \mathrm{C}$ and high stomatal sensitivity to seasonal soil drought in the tropical rainforest of French Guiana. Plant Cell Env 23:445-459

Bonal D, Bosc A, Goret JY, Burban B, Gross P, Bonnefond JM, Elbers J, Ponton S, Epron D, Guehl JM, Granier A (2008) The impact of severe dry season on net ecosystem exchange in the Neotropical rainforest of French Guiana. Glob Change Biol 14:1917-1933

Brando PM, Balch JK, Nepstad DC, Morton DC, Putz FE, Coe MT, Silvério D, Macedo MN, Davidson EA, Nóbrega CC, Alencar A, Soares-Filho BS (2014) Abrupt increases in Amazonian tree mortality due to drought-fire interactions. Proc Nat Acad Sci USA 111: $6347-6352$

Brando P, Nepstad DC, Davidson EA, Trumbore SE, Ray D, Camargo PB (2008) Drought effects on litterfall, wood production and belowground carbon cycling in an Amazon forest: results of a throughfall reduction experiment. Philo Trans R Soc B-Biol Sci 363:1839-1848

Brando PM, Goetz SJ, Baccini A, Nepstad DC, Beck PSA, Christman MC (2010) Seasonal and interannual variability of climate and vegetation indices across the Amazon. Proc Nat Acad Sci USA 107: $14685-14690$

Brienen RJW, Phillips OL, Feldpausch TR, Gloor E, Baker TR, Lloyd J, Lopez-Gonzalez G, Monteagudo-Mendoza A, Malhi Y, Lewis SL, Vasquez Martinez R, Alexiades M, Alvarez Davila E, AlvarezLoayza P, Andrade A, Aragao LEOC, Araujo-Murakami A, Arets EJMM, Arroyo L, Aymard CGA, Banki OS, Baraloto C, Barroso J, Bonal D, Boot RGA, Camargo JLC, Castilho CV, Chama V, Chao KJ, Chave J, Comiskey JA, Cornejo Valverde F, da Costa L, de Oliveira EA, Di Fiore A, Erwin TL, Fauset S, Forsthofer M, Galbraith DR, Grahame ES, Groot N, Hérault B, Higuchi N, Honorio Coronado EN, Keeling H, Killeen TJ, Laurance WF, Laurance S, Licona J, Magnussen WE, Marimon BS, MarimonJunior BH, Mendoza C, Neill DA, Nogueira EM, Nunez P, Pallqui Camacho NC, Parada A, Pardo-Molina G, Peacock J, Pena-Claros M, Pickavance GC, Pitman NCA, Poorter L, Prieto A, Quesada CA, Ramirez F, Ramirez-Angulo H, Restrepo Z, Roopsind A, Rudas A, Salomao RP, Schwarz M, Silva N, Silva-Espejo JE, Silveira M, Stropp J, Talbot J, ter Steege H, Teran-Aguilar J, Terborgh J, Thomas-Caesar R, Toledo M, Torello-Raventos M, Umetsu RK, van der Heijden GMF, van der Hout P, Guimaraes Vieira IC, Vieira SA, Vilanova E, Vos VA, Zagt RJ (2015) Long-term decline of the Amazon carbon sink. Nature 519:344-348

Cardinale BJ, Duffy JE, Gonzalez A, Hooper DU, Perrings C, Venail P, Narwani A, Mace GM, Tilman D, Wardle DA, Kinzig AP, Daily GC, Loreau M, Grace JB, Larigauderie A, Srivastava DS, Naeem S (2012) Biodiversity loss and its impact on humanity. Nature 486:5967

Carswell FE, Costa AL, Palheta M, Malhi Y, Meir P, Costa JdPR, Ruivo ML, Leal LSM, Costa JMN, Clement RJ, Grace J (2002) Seasonality in $\mathrm{CO}_{2}$ and $\mathrm{H}_{2} \mathrm{O}$ flux at an eastern Amazonian rain forest. J Geophys Res 107, D20, 8076. doi:10.1029/2000JD000284

Cattânio JH, Davidson EA, Nepstad DC, Verchot LV, Ackerman IL (2002) Unexpected results of a pilot throughfall exclusion experiment on soil emissions of $\mathrm{CO}_{2}, \mathrm{CH}_{4}, \mathrm{~N}_{2} \mathrm{O}$, and $\mathrm{NO}$ in eastern Amazonia. Biol Fertile Soil 36:102-108 
Cavaleri MA, Reed SC, Smith WK, Wood TE (2015) Urgent need for warming experiments in tropical forests. Glob Change Biol 21: 2111-2121

Cavender-Bares J, Bazzaz FA (2000) Changes in drought response strategies with ontogeny in Quercus rubra: implications for scaling from seedlings to mature trees. Oecologia 124:8-18

Cernusak LA, Winter K, Dalling JW, Holtum JAM, Jaramillo C, Körner C, Leakey ADB, Norby RJ, Poulter B, Turner BL, Wright SJ (2013) Tropical forest responses to increasing atmospheric $\mathrm{CO}_{2}$ : current knowledge and opportunities for future research. Funct Plant Biol 40:531-551

Chambers JQ, Higuchi N, Schimel JP, Ferreira LV, Melack JM (2000) Decomposition and carbon cycling of dead trees in tropical forests of the central Amazon. Oecologia 122:380-388

Chambers JQ, Schimel JP, Nobre AD (2001) Respiration from coarse wood litter in central Amazon forests. Biogeochem 52:115-31

Chave J (2014) Floristic shifts versus critical transitions in Amazonian forest systems. In: Burslem D, Coomes D (eds) Forests and global change. Cambridge University Press, Cambridge, pp 131-159

Chave J, Navarrete D, Alvarez AAE, Aragao LEOC, Bonal D, Chatelet P, Espejo JE, Goret JY, Von Hildebrand P, Jiménez E, Patino S, Penuela MC, Phillips OL, Stevenson PR, Malhi Y (2010) Regional and temporal patterns of litterfall in tropical South America. Biogeosci Discuss 7:43-55

Chitra-Tarak R, Ruiz L, Pulla S, Dattaraja HS, Suresh HS, Sukumar R (2015) And yet it shrinks: a novel method for correcting bias in forest tree growth estimates caused by water-induced fluctuations. For Ecol Manag 336:129-136

Ciais P, Reichstein M, Viovy N, Granier A, Ogee J, Allard V, Aubinet M, Buchmann N, Bernhofer C, Carrara A, Chevallier F, De Noblet N, Friend AD, Friedlingstein P, Grunwald T, Heinesch B, Keronen P, Knohl A, Krinner G, Loustau D, Manca G, Matteucci G, Miglietta F, Ourcival JM, Papale D, Pilegaard K, Rambal S, Seufert G, Soussana JF, Sanz MJ, Schulze ED, Vesala T, Valentini R (2005) Europe-wide reduction in primary productivity caused by the heat and drought in 2003. Nature 437:529-533

Clark DB, Clark DA, Oberbauer SF (2010) Annual wood production in a tropical rain forest in NE Costa Rica linked to climatic variation but not to increasing $\mathrm{CO}_{2}$. Glob Change Biol 16:747-759

Cleveland CC, Wieder WR, Reed SC, Townsend AR (2010) Experimental drought in a tropical rain forest increases soil carbon dioxide losses to the atmosphere. Ecol 91:2313-2323

Cochrane MA (2003) Fire science for rainforests. Nature 421:913-919

Cochrane MA, Alencar A, Schulze MD, Souza CM, Nepstad DC, Lefebvre P, Davidson EA (1999) Positive feedbacks in the fire dynamic of closed canopy tropical forests. Science 284:1832-1835

Cochrane MA, Barber CP (2009) Climate change, human land use and future fires in the Amazon. Glob Change Biol 15:601-612

Condit R (1998) Ecological implications of changes in drought patterns: shifts in forest composition in Panama. Clim Change 39:413-427

Condit R, Aguilar S, Hernandez A, Perez R, Lao S, Angehr G, Hubbell SP, Foster RB (2004) Tropical forest dynamics across a rainfall gradient and the impact of an El Nino dry season. J Trop Ecol 20:51-72

Condit R, Hubbell SP, Foster RB (1995) Mortality rates of 205 neotropical tree and shrub species and the impact of a severe drought. Ecol Monogr 65:419-439

Condit R, Hubbell SP, Foster RB (1996) Changes in tree species abundance in a Neotropical forest over eight years: impact of climate change. J Trop Ecol 12:231-256

Cox PM, Pearson D, Booth BB, Friedlingstein P, Huntingford C, Jones CD, Luke CM (2013) Sensitivity of tropical carbon to climate change constrained by carbon dioxide variability. Nature 494:341344

Cox PM, Betts RA, Collins M, Harris PP, Huntingford C, Jones CD (2004) Amazonian forest dieback under climate-carbon cycle projections for the 21st century. Theor Appl Climatol 78:137-156 da Costa ACL, Metcalfe DB, Dought CE, de Oliveira AAR, Neto GFC, da Costa MC, de Athaydes Silva Junior J, Aragão LEOC, Almeida S, Galbraith DR, Rowland LM, Meir P, Malhi Y (2014) Ecosystem respiration and net primary productivity after $8-10$ years of experimental through-fall reduction in an eastern Amazon forest. Plant Ecol Divers. doi:10.1080/17550874.2013.798366

da Costa AL, Galbraith D, Almeida S, Takeshi B, Portela T, da Costa M, Silva Junior J, Braga AP, de Gonçalves PHL, de Oliveira AA, Fisher RA, Phillips OL, Metcalfe DB, Levy PE, Meir P (2010) Effect of $7 \mathrm{yr}$ of experimental drought on vegetation dynamics and biomass storage of an eastern Amazonian rainforest. New Phytol 187:579591

Davidson EA, de Araujo AC, Artaxo P, Balch JK, Brown IF, C. Bustamante MM, Coe MT, DeFries RS, Keller M, Longo M, Munger JW, Schroeder W, Soares-Filho BS, Souza CM, Wofsy SC (2012) The Amazon basin in transition. Nature 481:321-328

Davidson EA, Nepstad DC, Ishida FY, Brando PM (2008) Effects of an experimental drought and recovery on soil emissions of carbon dioxide, methane, nitrous oxide, and nitric oxide in a moist tropical forest. Glob Change Biol 14:2582-2590

De Weirdt M, Verbeeck H, Maignan F, Peylin P, Poulter B, Bonal D, Ciais P, Steppe K (2012) Seasonal leaf dynamics for tropical evergreen forests in a process based global ecosystem model. Geosci Model Dev 5:1091-1108

Doughty CE, Malhi Y, Araujo-Murakami A, Metcalfe DB, Silva-Espejo JE, Arroyo L, Heredia JP, Pardo-Toledo E, Mendizabal LM, RojasLandivar VD, Vega-Martinez M, Flores-Valencia M, Sibler-Rivero R, Moreno-Vare L, Viscarra LJ, Chuviru-Castro T, Osinaga-Becerra M, Ledezma R (2014) Allocation trade-offs dominate the response of tropical forest growth to seasonal and interannual drought. Ecol 95:2192-2201

Engelbrecht BMJ, Comita LS, Condit R, Kursar TA, Tyree MT, Turner BL, Hubbell SP (2007) Drought sensitivity shapes species distribution patterns in tropical forests. Nature 447:80-82

Engelbrecht BMJ, Kursar TA (2003) Comparative drought-resistance of seedlings of 28 species of co-occurring tropical woody plants. Oecologia 136:383-393

Engelbrecht BMJ, Wright SJ, De Steven D (2002) Survival and ecophysiology of tree seedlings during El Nino drought in a tropical moist forest in Panama. J Trop Ecol 18:569-579

Enquist BJ, Enquist CAF (2010) Long-term change within a Neotropical forest: assessing differential functional and floristic responses to disturbance and drought. Glob Change Biol 17:1408-1424

Fisher RA, McDowell N, Purves D, Moorcroft P, Sitch S, Cox P, Huntingford C, Meir P, Woodward FI (2010) Assessing uncertainties in a second-generation dynamic vegetation model caused by ecological scale limitations. New Phytol 187:666-681

Fisher RA, Williams M, Da Costa AL, Malhi Y, da Costa RF, Almeida S, Meir P (2007) The response of an Eastern Amazonian rain forest to drought stress: results and modelling analyses from a throughfall exclusion experiment. Glob Change Biol 13:2361-2378

Fisher RA, Williams M, Do Vale RL, da Costa AL, Meir P (2006) Evidence from Amazonian forests is consistent with isohydric control of leaf water potential. Plant Cell Env 29:151-165

Forrester DI (2014) The spatial and temporal dynamics of species interactions in mixed-species forests: from pattern to process. For Ecol Manag 312:282-292

Fortunel C, Ruelle J, Beauchene J, Fine PVA, Baraloto C (2014) Wood specific gravity and anatomy of branches and roots in 113 Amazonian rainforest tree species across environmental gradients. New Phytol 202:79-94

Gatti LV, Gloor M, Miller JB, Doughty CE, Malhi Y, Domingues LG, Basso LS, Martinewski A, Correia CSC, Borges VF, Freitas S, Braz R, Anderson LO, Rocha H, Grace J, Phillips OL, Lloyd J (2014) Drought sensitivity of Amazonian carbon balance revealed by atmospheric measurements. Nature 506:76-80 
Gloor M, Gatti L, Brienen R, Feldpausch TR, Phillips OL, Miller J, Ometto JP, Rocha H, Baker T, de Jong B, Houghton RA, Malhi Y, Aragão LEOC, Guyot JL, Zhao K, Jackson R, Peylin P, Sitch S, Poulter B, Lomas M, Zaehle S, Huntingford C, Levy P, Lloyd J (2012) The carbon balance of South America: a review of the status, decadal trends and main determinants. Biogeosciences 9:54075430

Gloor M, Brienen RJW, Galbraith D, Feldpausch TR, Schöngart J, Guyot JL, Espinoza JC, Lloyd J, Phillips OL (2013) Intensification of the Amazon hydrological cycle over the last two decades. Geophys Res Lett 40:1729-1733

Goulden ML, Miller SD, Da Rocha HR, Menton MC, De Freitas HC, Silva Figueira AME, De Sousa CAD (2004) Diel and seasonal patterns of tropical forest $\mathrm{CO}_{2}$ exchange. Ecol Appl 14:42-54

Grace J, Mitchard E, Gloor E (2014) Perturbations in the carbon budget of the tropics. Glob Change Biol 20:3238-3255

Graham EA, Mulkey SS, Kitajima K, Phillips NG, Wright SJ (2003) Cloud cover limits net $\mathrm{CO}_{2}$ uptake and growth of a rainforest tree during tropical rainy seasons. Proc Nat Acad Sci USA 100:572-576

Grogan J, Schulze M (2012) The impact of annual and seasonal rainfall patterns on growth and phenology of emergent tree species in Southeastern Amazonia, Brazil. Biotrop 44:331-340

Hacke UG, Sperry JS, Pockman WT, Davis SD, McCulloh KA (2001) Trends in wood density and structure are linked to prevention of xylem implosion by negative pressure. Oecologia 126:457-461

Hartmann H, Adams HD, Anderegg WRL, Jansen S, Zeppel MJB (2015) Research frontiers in drought-induced tree mortality: crossing scales and disciplines. New Phytol 205:965-969

Hérault B, Beauchêne J, Muller F, Wagner F, Baraloto C, Blanc L, Martin JM (2010) Modeling decay rates of dead wood in a neotropical forest. Oecologia 164:243-51

Hilker T, Lyapustin AI, Tucker CJ, Hall FG, Myneni RB, Wang Y, Bi J, Mendes de Moura Y, Sellers PJ (2014) Vegetation dynamics and rainfall sensitivity of the Amazon. Proc Nat Acad Sci USA 111: 16041-16046

Holmgren M, Scheffer M, Ezcurra E, Gutierrez JR, Mohren GMJ (2001) El Nino effects on the dynamics of terrestrial ecosystems. Trends Ecol Evol 16:89-94

Huete AR, Didan K, Shimabukuro YE, Ratana P, Saleska SR, Hutyra LR, Yang W, Nemani RR, Myneni R (2006) Amazon rainforests greenup with sunlight in dry season. Geophys Res Lett 33:L06405. doi: 10.1029/2005GL025583

Hutyra LR, Munger JW, Saleska SC, Gottlieb E, Daube BC, Dunn AL, Amaral DF, De Camargo PB, Wofsy S (2007) Seasonal controls on the exchange of carbon and water in an Amazonian rain forest. J Geophys Res 112:G03008

Ichii K, Hashimoto H, Nemani R, White M (2005) Modeling the interannual variability and trends in gross and net primary productivity of tropical forests from 1982 to 1999. Glob Planet Change 48:274-286

Ichii K, Hashimoto H, White MA, Potter C, Hutyra LR, Huete AR, Myneni RB, Nemani RR (2007) Constraining rooting depths in tropical rainforests using satellite data and ecosystem modeling for accurate simulation of gross primary production seasonality. Glob Change Biol 13:67-77

Itoh A, Nanami S, Harata T, Ohkubo T, Tan S, Chong L, Davies SJ, Yamakura T (2012a) The effect of habitat association and edaphic conditions on tree mortality during El Niño-induced drought in a Bornean dipterocarp forest. Biotropica 44:606-617

Itoh M, Kosugi Y, Takanashi S, Kanemitsu S, Osaka K, Hayashi Y, Tani M, Rahim Nik A (2012b) Effects of soil water status on the spatial variation of carbon dioxide, methane and nitrous oxide fluxes in tropical rain-forest soils in Peninsular Malaysia. J Trop Ecol 28: $557-570$

Juarez RI, da Rocha HR, Figueira AMS, Goulden ML, Miller SD (2009) An improved estimate of leaf area index based on the histogram analysis of hemispherical photographs. Agric For Meteo 149:920 928

Keller M, Alencar A, Asner GP, Braswell B, Bustamante M, Davidson E, Feldpausch T, Fernandes E, Goulden M, Kabat P, Kruijt B, Luizão F, Miller S, Markewitz D, Nobre AD, Nobre CA, Priante Filho N, da Rocha H, Silva Dias P, von Randow C, Vourlitis GL (2004) Ecological research in the large-scale biosphere-atmosphere experiment in Amazonia: early results. Ecol Appl 14:3-16

Kim Y, Knox RG, Longo M, Medvigy D, Hutyra LR, Pyle EH, Wofsy SC, Bras RL, Moorcroft PR (2012) Seasonal carbon dynamics and water fluxes in an Amazon rainforest. Glob Change Biol 18:13221334

Kruijt B, Elbers JA, Von Randow C, Araujo AC, Olivieira PJ, Culf AD, Manzi AO, Nobre AD, Kabat P, Moors EJ (2004) The robustness of eddy correlation fluxes for Amazon rain forest conditions. Ecol Appl 14:101-113

Kursar TA, Coley PD (1992) Delayed development of the photosynthetic apparatus in tropical rainforest species. Funct Ecol 6:411-422

Lehto T, Zwiazek JJ (2011) Ectomycorrhizas and water relations of trees: a review. Mycorrhiza 21:71-90

Lewis SL, Brando PM, Phillips OL, Van der Heijden G, Nepstad DC (2011) The 2010 Amazon Drought. Science 331:554

Lewis SL, Lopez-Gonzalez G, Sonke B, Affum-Baffoe K, Baker TR, Ojo LO, Phillips OL, Reitsma JM, White L, Comiskey JA, M-ND K, Ewango CEN, Feldpausch TR, Hamilton AC, Gloor M, Hart T, Hladik A, Lloyd J, Lovett JC, Makana J-R, Malhi Y, Mbago FM, Ndangalasi HJ, Peacock J, Peh KSH, Sheil D, Sunderland T, Swaine MD, Taplin J, Taylor D, Thomas SC, Votere R, Woll H (2009) Increasing carbon storage in intact African tropical forests. Nature 457:1003-1006

Li W, Fu R, Dickinson RE (2006) Rainfall and its seasonality over the Amazon in the 21st century as assessed by the coupled models for the IPCC AR4. J Geophys Res 111:D02111

Liu KB, Colinvaux PA (1985) Forest changes in the Amazon Basin during the last glacial maximum. Nature 318:556-557

Lopez OR, Kursar T, Cochard H, Tyree MT (2005) Interspecific variation in xylem vulnerability to cavitation among tropical tree and shrub species. Tree Physiol 25:1553-1562

Loubry D (1994) Déterminismes du comportement phénologique des arbres en forêt tropicale humide de Guyane Française. Dissertation, Thèse de l'Université Paris VI. France

Maeda EE, Heiskanen J, Aragão LEOC, Rinne J (2014) Can MODIS EVI monitor ecosystem productivity in the Amazon rainforest? Geophys Res Lett 41:7176-7183

Malhado ACM, Costa MH, de Lima FZ, Portilho KC, Figueiredo DN (2009) Seasonal leaf dynamics in an Amazonian tropical forest. For Ecol Manag 258:1161-1165

Malhi Y, Amézquita FF, Doughty CE, Silva-Espejo JE, Girardin CAJ, Metcalfe DB, Aragão LEOC, Huaraca-Quispe LP, Alzamora-Taype I, Eguiluz-Mora L, Marthews TR, Halladay K, Quesada CA, Robertson AL, Fisher JB, Zaragoza-Castells J, Rojas-Villagra CM, Pelaez-Tapia Y, Salinas N, Meir P, Phillips OL (2014) The productivity, metabolism and carbon cycle of two lowland tropical forest plots in south-western Amazonia, Peru. Plant Ecol Divers. doi:10. 1080/17550874.2013.820805

Malhi Y, Aragão LEOC, Galbraith D, Huntingford C, Fisher R, Zelazowski P, Sitch S, McSweeney C, Meir P (2009) Exploring the likelihood and mechanism of a climate-change-induced dieback of the Amazon rainforest. Proc Nat Acad Sci 106:20610-20615

Malhi Y, Baker TR, Phillips OL, Almeida S, Alvarez E, Arroyo L, Chave J, Czimczik CI, Di Fiore A, Higuchi N, Killeen TJ, Laurance SG, Laurance WF, Lewis SL, Montoya LMM, Monteagudo A, Neill DA, Vargas PN, Patino S, Pitman NCA, Quesada CA, Salomao R, Silva J, Lezama AT, Martinez RV, Terborgh J, Vinceti B, Lloyd J (2004) The above-ground coarse wood productivity of 104 Neotropical forest plots. Glob Change Biol 10:563-591 
Marengo J, Nobre C, Tomasella J, Cardoso M, Oyama M (2008) Hydroclimatic and ecological behaviour of the drought of Amazonia in 2005. Philo Trans R Soc B: Biol Sci 363:1773-1778

Marengo JA, Tomasella J, Alves LM, Soares WR, Rodriguez DA (2011) The drought of 2010 in the context of historical droughts in the Amazon region. Geophys Res Lett 38:L12703

Markewitz D, Devine S, Davidson E, Brando PM, Nepstad DC (2010) Soil moisture depletion under simulated drought in the Amazon: impacts on deep root uptake. New Phytol 187:592-607

Mayle FE, Burbridge R, Killeen TJ (2000) Millennial-scale dynamics of southern Amazonian rain forests. Science 290:2291-2294

Mayle FE, Power MJ (2008) Impact of a drier Early-Mid-Holocene climate upon Amazonian forests. Philo Trans R Soc B: Biol Sci 363:1829-1838

McDowell NG, Pockman WT, Allen C, Breshears D, Cobb N, Kolb T, Sperry JS, West A, Williams D, Yepez EA (2008) Mechanisms of plant survival and mortality during drought: Why do some plants survive while others succumb to drought? New Phytol 178:719-739

McDowell NG, Fisher RA, Xu C, Domec JC, Hölttä T, Mackay DS, Sperry JS, Boutz A, Dickman L, Gehres N, Limousin JM, Macalady A, Martínez-Vilalta J, Mencuccini M, Plaut JA, Ogée J, Pangle RE, Rasse DP, Ryan MG, Sevanto S, Waring RH, Williams AP, Yepez EA, Pockman WT (2013) Evaluating theories of droughtinduced vegetation mortality using a multimodel-experiment framework. New Phytol 200:304-321

Metcalfe DB, Meir M, Aragao L, Lobo-do-Vale R, Galbraith D, Fisher RA, Chaves MM, Maroco JP, da Costa ACL, de Almeida SS, Braga AP, Gonçalves PHL, de Athaydes J, da Costa M, Portela T, de Oliveira AA, Malhi Y, Williams M (2010a) Shifts in plant respiration and carbon use efficiency at a large-scale drought experiment in the eastern Amazon. New Phytol 187:608-621

Metcalfe DB, Lobo-do-Vale R, Chaves MM, Maroco JP, Aragão LEOC, Malhi Y, Costa ALD, Braga AP, Gonçalves PL, Athaydes JD, Costa MD, Almeida SS, Campbell C, Hurry V, Williams M, Meir P (2010b) Impacts of experimentally imposed drought on leaf respiration and morphology in an Amazon rain forest. Funct Ecol 24:524-533

Miranda LDPD, Vitoria AP, Funch LS (2011) Leaf phenology and water potential of five arboreal species in gallery and montane forests in the Chapada Diamantina, Bahia; Brazil. Env Exp Bot 70:143-150

Mouillot D, Bellwood DR, Baraloto C, Chave J, Galzin R, HarmelinVivien M, Kulbicki M, Lavergne S, Lavorel S, Mouquet N, Paine CET, Renaud J, Thuiller W (2013) Rare species support vulnerable functions in high-diversity ecosystems. PLoS Biol 11:e1001569. doi:10.1371/journal.pbio.1001569

Morton DC, Nagol J, Carabajal CC, Rosette J, Palace M, Cook BD, Vermote EF, Harding DJ, North PRJ (2014) Amazon forests maintain consistent canopy structure and greenness during the dry season. Nature 506:221-224

Moser G, Schuldt B, Hertel D, Horna V, Coners H, Barus H, Leuschner C (2014) Replicated throughfall exclusion experiment in an Indonesian perhumid rainforest: wood production, litter fall and fine root growth under simulated drought. Glob Change Biol 20:1481-1497

Nepstad D, Tohver IM, Ray D, Moutinho P, Cardinot G (2007) Mortality of large trees and lianas following experimental drought in an Amazon forest. Ecology 88:2259-2269

Nepstad DC, Verssimo A, Alencar A, Nobre C, Lima E, Lefebvre P, Schlesinger P, Potter C, Moutinho P, Mendoza E, Cochrane M, Brooks V (1999) Large-scale impoverishment of Amazonian forests by logging and fire. Nature 398:505-508

Nepstad DC, De Carvalho CR, Davidson EA, Jipp PH, Lefebvre PA, Negreiros GH, Da Silva ED, Stone TA, Trumbore SE, Vieira S (1994) The role of deep roots in the hydrological and carbon cycles of Amazonian forests and pastures. Nature 372:666-669

Nepstad D, Lefebvre P, Lopes da Silva U, Tomasella J, Schlesinger P, Solórzano L, Moutinho P, Ray D, Guerreira Benito J (2004) Amazon drought and its implications for forest flammability and tree growth: a basin-wide analysis. Glob Change Biol 10:704-717
Nepstad DC, Moutinho P, Dias-Filho MB, Davidson E, Cardinot G, Markewitz D, Figueiredo RO, Vianna N, Chambers J, Ray D, Guerreiros JB, Lefebvre P, Sternberg L, Moreira M, Barros L, Ishida FY, Tohlver I, Belk E, Kalif K, Schwalbe K (2002) The effects of partial throughfall exclusion on canopy processes, aboveground production, and biogeochemistry of an Amazon forest. J Geophys Res 107:8085

Niinemets $\ddot{U}$ (2010) Responses of forest trees to single and multiple environmental stresses from seedlings to mature plants: past stress history, stress interactions, tolerance and acclimation. For Ecol Manag 260:1623-1639

Nishimua TB, Suzuki E, Kohyama T, Tsuyuzaki S (2007) Mortality and growth of trees in peat-swamp and heath forests in central Kalimantan after severe drought. Plant Ecol 188:165-177

Obrien MJ, Leuzinger S, Philipson CD, Tay J, Hector A (2014) Drought survival of tropical tree seedlings enhanced by non-structural carbohydrate levels. Nat Clim Change 4:710-714

Ouédraogo D-Y, Mortier F, Gourlet-Fleury S, Freycon V, Picard N (2013) Slow-growing species cope best with drought: evidence from longterm measurements in a tropical semi-deciduous moist forest of Central Africa. J Ecol 101:1459-1470

Pan Y, Birdsey RA, Fang J, Houghton R, Kauppi PE, Kurz WA, Phillips OL, Shvidenko A, Lewis SL, Canadell JG, Ciais P, Jackson RB, Pacala SW, McGuire AD, Piao S, Rautiainen A, Sitch S, Hayes D (2011) A large and persistent carbon sink in the world's forests. Science 333:988-993

Peay KG, Baraloto C, Fine PVA (2013) Strong coupling of plant and fungal community structure across western Amazonian rainforests. Multidiscip J Microb Ecol 7:1852-1861

Phillips OL, Aragao LEOC, Lewis SL, Fisher JB, Lloyd J, LopezGonzales G, Malhi Y, Monteagudo A, Peacock J, Quesada CA, Van Der Heijden G, Almeida S, Amaral I, Arroyo L, Aymard G, Baker TR, Banki O, Blanc L, Bonal D, Brando P, Chave J, Alves de Oliveira AC, Cardozo ND, Czimczik CI, Feldpausch TR, Freitas MA, Gloor E, Higuchi N, Jimenez E, Lloyd G, Meir P, Mendoza C, Morel A, Neill DA, Nepstad D, Patino S, Penuela MC, Prieto A, Ramirez F, Schwarz M, Silva J, Silveira M, Thomas AS, Ter Steege H, Stropp J, Vasquez R, Zelazowski P, Davila EA, Andelman S, Andrade A, Chao K-J, Erwin T, Di Fiore A, Honorio E, Keeling H, Killeen TJ, Laurance WF, Pena Cruz A, Pitman NCA, Nunez Vargas P, Ramirez-Angulo H, Rudas A, Salamao R, Silva N, Terborgh J, Torres-Lezama A (2009) Drought sensitivity of the Amazon rainforest. Science 323:1344-1347

Phillips OL, Lewis S (2014) Recent changes in tropical forest biomass and dynamics. In: Burslem D, Coomes D (eds) Forests and global change. Cambridge University Press, Cambridge, pp 77-108

Phillips OL, Van Der Heijden G, Lewis SL, Lopez-Gonzales G, Aragao LEOC, Lloyd J, Malhi Y, Monteagudo A, Almeida S, Alvarez Davila E, Amaral I, Andelman S, Andrade A, Arroyo L, Aymard G, Baker TR, Blanc L, Bonal D, Alves de Oliveira AC, Chao K-J, Cardozo ND, Da Costa L, Feldpausch TR, Fisher JB, Fyllas NM, Freitas MA, Galbraith D, Gloor E, Higuchi N, Honorio E, Jimenez E, Keeling H, Killeen TJ, Lovett JC, Meir P, Mendoza C, Morel A, Vargas PN, Patino S, Peh KS-H, Cruz AP, Prieto A, Quesada CA, Ramirez F, Ramirez H, Rudas A, Salamao R, Schwarz M, Silva J, Silveira M, Ferry Slik JW, Sonke B, Thomas AS, Stropp J, Taplin JRD, Vasquez R, Vilanova E (2010) Drought-mortality relationships for tropical forests. New Phytol 187:631-646

Potvin C, Gotelli NJ (2008) Biodiversity enhances individual performance but does not affect survivorship in tropical trees. Ecol Lett $11: 217-223$

Poulter B, Hattermann F, Hawkins E, Zaehle S, Sitch S, Restrepo-Coupe N, Heyder U, Cramer W (2010) Robust dynamics of Amazon dieback to climate change with perturbed ecosystem model parameters. Glob Change Biol 16:2476-2495 
Powell TL, Galbraith DR, Christoffersen BO, Harper A, Imbuzeiro HMA, Rowland L, Almeida S, Brando PM, da Costa ACL, Costa MH, Levine NM, Malhi Y, Saleska SR, Sotta E, Williams M, Meir P, Moorcroft PR (2013) Confronting model predictions of carbon fluxes with measurements of Amazon forests subjected to experimental drought. New Phytol 200:350 365

Restrepo-Coupe N, da Rocha HR, Hutyra LR, da Araujo AC, Borma LS, Christoffersen B, Cabral OMR, de Camargo PB, Cardoso FL, da Costa ACL, Fitzjarrald DR, Goulden ML, Kruijt B, Maia JMF, Malhi YS, Manzi AO, Miller SD, Nobre AD, von Randow C, Sá LDA, Sakai RK, Tota J, Wofsy SC, Zanchi FB, Saleska SR (2013) What drives the seasonality of photosynthesis across the Amazon basin? A cross-site analysis of eddy flux tower measurements from the Brasil flux network. Agric For Meteorol 182-183:128-144

Richardson AD, Carbone MS, Keenan TF, Czimczik CI, Hollinger DY, Murakami P, Schaberg PG, Xu X (2013) Seasonal dynamics and age of stemwood nonstructural carbohydrates in temperate forest trees. New Phytol 197:850-861

Rowland L, Hill T, Stahl C, Siebicke L, Burban B, Zaragoza-Castells J, Ponton S, Bonal D, Meir P, Williams M (2014) Evidence for strong seasonality in the carbon storage and carbon use efficiency of an Amazonian forest. Glob Change Biol 20:979-991

Rowland L, Stahl C, Bonal D, Siebicke L, Williams M, Meir P (2013) The response of tropical rainforest dead wood respiration to seasonal drought. Ecosystems 16:1294-1309

Saatchi S, Asefi-Najafabady S, Malhi Y, Aragão LEOC, Anderson LO, Myneni RB, Nemani R (2013) Persistent effects of a severe drought on Amazonian forest canopy. Proc Nat Acad Sci 110:565-570

Sakaguchi K, Zeng X, Christoffersen BJ, Restrepo-Coupe N, Saleska SR, Brando PM (2011) Natural and drought scenarios in an east central Amazon forest: fidelity of the Community Land Model 3.5 with three biogeochemical models. J Geophys Res 116:G01029

Saldarriaga JG, West DC (1986) Holocene fires in the northern Amazon basin. Quat Res 26:358-366

Saleska SC, Miller SD, Matross DM, Goulden ML, Wofsy SC, Rocha HR, De Camargo PB, Crill P, Daube BC, de Freitas HC, Hutyra L, Keller M, Kirchhoff V, Menton M, Munger JW, Pyle EH, Rice AH, Silva H (2003) Carbon in amazon forests: unexpected seasonal fluxes and disturbance-induced losses. Science 302:1554-1557

Saleska SR, Didan K, Huete AR, da Rocha HR (2007) Amazon forests green-up during 2005 drought. Science (80) 318612

Samanta A, Ganguly S, Hashimoto H, Devadiga S, Vermote E, Knyazikhin Y, Nemani RR, Myneni RB (2010) Amazon forests did not green-up during the 2005 drought. Geophys Res Lett 37: L05401. doi:10.1029/2009GL042154

Samanta A, Knyazikhin Y, Xu L, Dickinson RE, Fu R, Costa MH, Saatchi SS, Nemani RR, Myneni RB (2012) Seasonal changes in leaf area of Amazon forests from leaf flushing and abscission. J Geophys Res: Biogeosci 117:G01015. doi:10.1029/ 2011JG00181

Schnitzer SA (2005) A mechanistic explanation for global patterns of liana abundance and distribution. Am Nat 166:262-276

Schnitzer SA, Bongers F (2011) Increasing liana abundance and biomass in tropical forests: emerging patterns and putative mechanisms. Ecol Lett 14:397-406

Sevanto S, McDowell NG, Dickman LT, Pangle R, Pockman WT (2014) How do trees die? A test of the hydraulic failure and carbon starvation hypotheses. Plant Cell Env 37:153-161

Shi Z, Thomey ML, Mowll W, Litvak M, Brunsell NA, Collins SL, Pockman WT, Smith MD, Knapp AK, Luo Y (2014) Differential effects of extreme drought on production and respiration: synthesis and modeling analysis. Biogeosciences 11:621-633
Siegert F, Ruecker G, Hinrichs A, Hoffmann AA (2001) Increased damage from fires in logged forests during droughts caused by El Niño. Nature 414:437-440

Silva CE, Kellner JR, Clark DB, Clark DA (2013) Response of an oldgrowth tropical rainforest to transient high temperature and drought. Glob Change Biol 19:3423-3434

Sitch S, Huntingford C, Gedney N, Levy PE, Lomas M, Piao SL, Betts R, Ciais P, Cox P, Friedlingstein P, Jones CD, Prentice IC, Woodward FI (2008) Evaluation of the terrestrial carbon cycle, future plant geography and climate-carbon cycle feedbacks using five Dynamic Global Vegetation Models (DGVMs). Glob Change Biol 14:2015-2039

Slik JWF (2004) El Nino droughts and their effects on tree species composition and diversity in tropical rain forests. Oecologia 141:114 120

Sobrado MA (1997) Embolism vulnerability in drought-deciduous and evergreen species of a tropical dry forest. Acta Oecol 18:383-391

Sotta ED, Veldkamp E, Schwendenmann L, Guimaraes BR, Paixao RK, Ruivo MLP, Lola Da Costa AC, Meir P (2007) Effects of an induced drought on soil carbon dioxide $\left(\mathrm{CO}_{2}\right)$ efflux and soil $\mathrm{CO}_{2}$ production in an Eastern Amazonian rainforest, Brazil. Glob Change Biol 13: 2218-2229

Stahl C, Burban B, Goret JY, Bonal D (2011) Seasonal variations in stem $\mathrm{CO}_{2}$ efflux in the Neotropical rainforest of French Guiana. Ann For Sci 68:771-782

Stahl C, Burban B, Bompy F, Jolin ZB, Sermage J, Bonal D (2010) Seasonal variation in atmospheric relative humidity contributes to explaining seasonal variation in trunk circumference of tropical rain forest trees in French Guiana. J Trop Ecol 26:393-405

Stahl C, Burban B, Wagner F, Goret JY, Bompy F, Bonal D (2013a) Influence of seasonal variations in soil water availability on gas exchange of tropical canopy trees. Biotropica 45:155-164

Stahl C, Hérault B, Rossi V, Burban B, Brechet C, Bonal D (2013b) Depth of soil water uptake by tropical rainforest trees during dry periods: does tree dimension matter? Oecologia 173:1191-1201

Steinkamp J, Hickler T (2015) Is drought-induced forest dieback globally increasing? J Ecol 103:31-43

Tan Z-H, Cao M, Yu G-R, Tang J-W, Deng X-B, Song Q-H, Tang Y, Zheng Z, Liu W-J, Feng Z-L, Deng Y, Zhang J-L, Liang N, Zhang Y-P (2013) High sensitivity of a tropical rainforest to water variability: evidence from 10 years of inventory and eddy flux data. J Geophys Res Atmos 118:9393-9400

Tardieu F, Parent B, Simonneau T (2010) Control of leaf growth by abscisic acid: hydraulic or non-hydraulic processes? Plant Cell Env 33:636-647

Tardieu F, Simonneau T (1998) Variability among species of stomatal control under fluctuating soil water status and evaporative demand: modelling isohydric and anisohydric behaviors. J Exp Bot 49s:419 432

Tian H, Melillo JM, Kicklighter DW, Mc Guire AD, Helfrich JVKI, Moore BI, Vörösmarty CJ (1998) Effect of interannual climate variability on carbon storage in Amazonian ecosystems. Nature 396: 664-667

Tyree MT, Cochard H (1996) Summer and winter embolism in oakimpact on water relations. Ann For Sci 53:173-180

van der Molen MK, Dolman AJ, Ciais P, Eglin T, Gobron N, Law BE, Meir P, Peters W, Phillips OL, Reichstein M, Chen T, Dekker SC, Doubková M, Friedl MA, Jung M, van den Hurk BJJM, de Jeu RAM, Kruijt B, Ohta T, Rebel KT, Plummer S, Seneviratne SI, Sitch S, Teuling AJ, van der Werf GR, Wang G (2011) Drought and ecosystem carbon cycling. Agric For Meteorol 151:765-773

van der Sleen P, Groenendijk P, Vlam M, Anten NPR, Boom A, Bongers F, Pons TL, Terburg G, Zuidema PA (2015) No growth stimulation of tropical trees by 150 years of $\mathrm{CO}_{2}$ fertilization but water-use efficiency increased. Nature Geosci 8:24-28 
van Straaten O, Veldkamp E, Corre MD (2011) Simulated drought reduces soil $\mathrm{CO}_{2}$ efflux and production in a tropical forest in Sulawesi, Indonesia. Ecosphere 2:art119. doi:10.1890/ES11-00079.1

Viennois G, Barbier N, Fabre I, Couteron P (2013) Multiresolution quantification of deciduousness in West-Central African forests. Biogeosciences 10:6957-6967

Wagner F, Hérault B, Stahl C, Bonal D, Rossi V (2011) Modeling water availability for trees in tropical forests. Agric For Meteorol 151: $1202-1213$

Wagner F, Rossi V, Stahl C, Bonal D, Hérault B (2012) Water availability is the main climate driver of neotropical tree growth. Plos One 7. doi:10.1371/journal.pone.0034074

Wagner F, Rossi V, Stahl C, Bonal D, Hérault B (2013) Asynchronism in leaf and wood production in tropical forests: a study combining satellite and ground-based measurements. Biogeosciences 10: 7307-7321. doi:10.5194/bg-10-7307-2013

Wagner F, Rossi V, Aubry-Kientz M, Bonal D, Dalitz H, Gliniars R, Stahl C, Trabucco A, Hérault B (2014) Pan-Tropical analysis of climate effects on seasonal tree growth. Plos One 9. doi:10.1371/journal. pone. 0092337

Williams M, Malhi Y, Nobre AD, Rastetter EB, Grace J, Pereira MGP (1998) Seasonal variation in net carbon exchange and evapotranspiration in a Brazilian rain forest: a modelling analysis. Plant Cell Env 21:953-968

Williamson GB, Laurance WF, Oliveira AA, Delamonica P, Gascon C, Lovejoy TE, Pohl L (2000) Amazonian tree mortality during the 1997 El Niño drought. Conserv Biol 14:1538-1542
Wood TE, Silver WL (2012) Strong spatial variability in trace gas dynamics following experimental drought in a humid tropical forest. Global Biogeochem Cycle 26:GB3005. doi:10.1029/2010GB004014

Wright SJ, van Schaik CP (1994) Light and the phenology of tropical trees. Am Nat 143:192-199

Wright SJ, Cornejo FH (1990) Seasonal drought and leaf fall in a tropical forest. Ecology 71:1165-1175

Würth MKR, Pelaez-Riedl S, Wright SJ, Körner C (2005) Non-structural carbohydrate pools in a tropical forest. Oecologia 143:11-24

Xiao X, Hagen S, Zhang G, Keller M, Moore BI (2006) Detecting leaf phenology of seasonally moist tropical forests in South America with multi-temporal MODIS images. Remote Sens Env 103:465473

Xu L, Samanta A, Costa MH, Ganguly S, Nemani RR, Myneni RB (2011) Widespread decline in greenness of Amazonian vegetation due to the 2010 drought. Geophys Res Lett 38:L07402. doi:10. 1029/2011GL046824

Yachi S, Loreau M (1999) Biodiversity and ecosystem productivity in a fluctuating environment: the insurance hypothesis. Proc Nat Acad Sci USA 96:1463-1468

Yan J, Zhang W, Wang K, Qin F, Wang W, Dai H, Li P (2014) Responses of $\mathrm{CO}_{2}, \mathrm{~N}_{2} \mathrm{O}$ and $\mathrm{CH}_{4}$ fluxes between atmosphere and forest soil to changes in multiple environmental conditions. Glob Change Biol 20:300-312

Yan J, Zhang Y, Yu G, Zhou G, Zhang L, Li K, Tan Z, Sha L (2013) Seasonal and inter-annual variations in net ecosystem exchange of two old-growth forests in southern China. Agric For Meteorol 182: 257-265 